\title{
A high-definition spatially explicit modelling approach for national greenhouse gas emissions from industrial processes: reducing the errors and uncertainties in global emission modelling
}

\author{
Nadiia Charkovska ${ }^{1}$ - Mariia Halushchak ${ }^{1,2} \cdot$ Rostyslav Bun ${ }^{1,3}$. \\ Zbigniew Nahorski $^{4,5}$ (D) Tomohiro Oda $^{6,7} \cdot$ Matthias Jonas $^{2} \cdot$ Petro Topylko $^{1}$
}

Received: 30 May 2018 / Accepted: 21 December 2018 / Published online: 10 January 2019

(C) The Author(s) 2019

\begin{abstract}
Industrial processes cause significant emissions of greenhouse gases (GHGs) to the atmosphere and, therefore, have high mitigation and adaptation potential for global change. Spatially explicit (gridded) emission inventories (EIs) should allow us to analyse sectoral emission patterns to estimate the potential impacts of emission policies and support decisions on reducing emissions. However, such EIs are often based on simple downscaling of national level emission estimates and the changes in subnational emission distributions do not necessarily reflect the actual changes driven by the local emission drivers. This article presents a high-definition, 100-m resolution bottom-up inventory of GHG emissions from industrial processes (fuel combustion activities in energy and manufacturing industries, fugitive emissions, mineral products, chemical industries, metal production and food and drink industries), which is exemplified for data for Poland. The study objectives include elaboration of the universal approach for mapping emission sources, algorithms for emission disaggregation,
\end{abstract}

Electronic supplementary material The online version of this article (https://doi.org/10.1007/s11027-0189836-6) contains supplementary material, which is available to authorized users.

Zbigniew Nahorski

Zbigniew.Nahorski@ibspan.waw.pl

1 Lviv Polytechnic National University, Lviv, Ukraine

2 International Institute for Applied Systems Analysis, Laxenburg, Austria

3 WSB University, Dąbrowa Górnicza, Poland

4 Systems Research Institute, Polish Academy of Sciences, Warsaw, Poland

5 Warsaw School of Information Technology, Warsaw, Poland

6 Global Modeling and Assimilation Office, NASA Goddard Space Flight Center, Greenbelt, MD, USA

7 Goddard Earth Sciences Technology and Research, Universities Space Research Association, Columbia, MD, USA 
estimation of emissions at the source level and uncertainty analysis. We start with IPCCcompliant national sectoral GHG estimates made using Polish official statistics and, then, propose an improved emission disaggregation algorithm that fully utilises a collection of activity data available at the national/provincial level to the level of individual point and diffused (area) emission sources. To ensure the accuracy of the resulting 100-m resolution emission fields, the geospatial data used for mapping emission sources (point source geolocation and land cover classification) were subject to thorough human visual inspection. The resulting 100-m emission field even holds cadastres of emissions separately for each industrial emission category. We also compiled cadastres in regular grids and, then, compared them with the Emission Database for Global Atmospheric Research (EDGAR). A quantitative analysis of discrepancies between both results reveals quite frequent misallocations of point sources used in the EDGAR compilation that considerably deteriorate high-resolution inventories. We also use a Monte-Carlo method-based uncertainty assessment that yields a detailed estimation of the GHG emission uncertainty in the main categories of the analysed processes. We found that the above-mentioned geographical coordinates and patterns used for emission disaggregation have the greatest impact on the overall uncertainty of GHG inventories from the industrial processes. We evaluate the mitigation potential of industrial emissions and the impact of separate emission categories. This study proposes a method to accurately quantify industrial emissions at a policy relevant spatial scale in order to contribute to the local climate mitigation via emission quantification (local to national) and scientific assessment of the mitigation effort (national to global). Apart from the above, the results are also of importance for studies that confront bottom-up and top-down approaches and represent much more accurate data for global high-resolution inventories to compare with.

Keywords Greenhouse gas emission · Industrial sector · Manufacturing industry · Fugitive emission $\cdot$ Spatial inventory $\cdot$ Uncertainty analysis $\cdot$ Monte-Carlo method

\section{Introduction}

Atmospheric measurements reveal that the concentration of carbon dioxide $\left(\mathrm{CO}_{2}\right)$ and other greenhouse gases (GHGs) has increased more than 20\% compared to 1958 (IPCC 2013). This negative tendency causes climatic changes, increased frequency of natural disasters and other adverse phenomena (IPCC 2014). Mitigation and adaptation strategies have been proposed to minimise global warming and its impact. The international community has signed a number of agreements to reduce anthropogenic emissions of GHGs, including the Kyoto protocol (UNFCCC 1998) and Paris Agreement (UNFCCC 2015), which introduced mechanisms for emission reduction and flexible mechanisms of quota trading.

An important role in the practical implementation of these mechanisms is played by national inventory reports (NIRs) to the United Nations Framework Convention on Climate Change (UNFCCC 2017). NIRs are prepared according to GHG inventory guidelines (IPCC 2006) that also stipulate consideration of inventory uncertainty (IPCC 2001). Hence, the national inventories of GHG emissions are key elements in the global system of monitoring and control of climate change. The scientific community has intensively engaged in improving GHG inventory methodologies, the elaboration of the mathematical models of the emission processes and the software tools that support them. The development of the mathematical models is an important task in the estimation of emissions, since direct measurements of 
emissions are either too costly or effective methods to achieve it are not known (Le Quéré et al. 2015; Lamarque et al. 2013).

The categories of anthropogenic activity that cause GHG emissions are specified in the IPCC (2006) Guidelines and are broken up into sectors, subsectors and categories. All these emissions are summed up in the NIRs. Industrial processes with fossil fuel combustion, fugitive processes and chemical transformation of materials are sources of high anthropogenic GHG emissions and, therefore, have essential mitigation potential to reduce them. A variety of industrial processes that emit GHGs are included in different sectors of activity categories in the IPCC (2006) classification. The highest emissions come from electricity generation and heat production ( $\sim 49 \%$ of global GHG emissions from the fuel combustion in 2014 (WB 2018)). Hence, emissions in the category 1.A.1.a Public Electricity and Heat Production (according to the IPCC classification) dominate in practically all NIRs. These kinds of GHG emissions, particularly from large point emission sources of electric power plants, are, for example, assembled in the Carbon Monitoring for Action (CARMA 2017) database and have been analysed in many publications (e.g. Singer et al. 2014; Pétron et al. 2008; Tong et al. 2018; Kiemle et al. 2017; Hondo 2005; Topylko et al. 2015), where peculiarities of technological processes and fuels were investigated, as well as the mitigation potential for the reduction of GHG emissions. However, other industrial emission categories, with a greater variety of GHG emission processes, have not been investigated so actively. Pertaining publications include those on fugitive emission from the mining industry (Cheng et al. 2011; Shao et al. 2016; Su et al. 2005; Warmuzinski 2008); oil and natural gas (Elgowainy et al. 2014; Elkin 2015; Motazedi et al. 2017; Park et al. 2010; Szklo and Schaeffer 2007; Schneising et al. 2014); fossil fuel GHG emissions from the manufacturing industry (Akbostanci et al. 2011; Griffina et al. 2018; Laurent et al. 2010; Lina and Xubc 2018; Pengab et al. 2018; Ren et al. 2014; Tian et al. 2013; Yuab et al. 2018); emissions from the mineral products, especially cement (Andrew 2018; Cai et al. 2016; Liu et al. 2015; Liu 2016; Rehan and Nehdi 2005; Shan et al. 2016); and metal (Hao et al. 2016; Liu et al. 2016; Shi and Zhao 2016; Yang et al. 2018) and food (Garnett 2011) productions. Important information was brought during assessments of mitigation potential of the industrial processes on the reduction of GHG emissions (Garnett 2011; Hao et al. 2016; Laurent et al. 2010; Liu et al. 2014; Long et al. 2016; Park et al. 2010; Rehan and Nehdi 2005; Wu et al. 2016; Yu et al. 2016; Zhang et al. 2016). Furthermore, a recent special issue of Applied Energy was published on the recent trends of industrial emissions in developing countries (Geng et al. 2016).

Polish industry plays a vital role in the reduction of GHG emissions and mitigation potential at the global scale. Poland, which heavily relies on coal, is among countries, like the USA, China, India and Australia, that have to undertake a transition to more environmentally friendly energy sources and technologies. The share of total emissions from industrial processes in Poland (caused by fossil fuel combustion in the energy industry, the manufacturing industry, fugitive processes and the chemical transformation of materials) is $\sim 67.3 \%$ of the national total GHG emissions (NIR 2012). This is why the analysis of GHG emissions from Polish industry is of wider importance.

National inventories of GHG emissions are indispensable for monitoring and control of climate change but give no information on the spatial pattern of emissions. Methods of spatial inventories have proved to be helpful for policymakers, particularly at regional level (Olivier et al. 2005; Andres et al. 2009; Gurney et al. 2009; Gurney et al. 2012; Raupach et al. 2010; Rayner et al. 2010; Oda and Maksyutov 2011, 2015; Puliafito et al. 2015; EDGAR 2013; Hutchins et al. 2017, Oda et al. 2018). Another important area where 
spatial inventories are indispensable is the modelling of local GHG dispersion in the atmosphere in order to compare the results with the atmospheric concentration measurements, checking the inventory accuracy or improving the emission estimates (Oda et al. 2018; Peylin et al. 2011; Liu et al. 2017). This is connected with more and more popular stationary or air-borne measurement equipment installed close to strong emission sources. High-resolution inventories improve the accuracy of such modelling, particularly due to very non-homogeneous anthropogenic emissions. Industrial processes are not only very dispersed spatial emission sources, but also are the main emitters of GHGs (processes of electricity and heat production caused $25 \%$ of 2010 global GHG emissions; industrial processes of fossil fuel burning, as well as chemical, metallurgical and mineral transformation processes not associated with energy consumption, caused $21 \%$ of the global emissions (EPA 2018)). This makes modelling of the GHG emissions from industrial processes an important factor in better understanding and assessing the fate of atmospheric carbon.

As a rule, spatial inventories are given in regular grids, where the cell sizes have decreased to $1^{\circ}$ latitude and longitude (Andres et al. 1996) and then to $1 \mathrm{~km}$ (Oda and Maksyutov 2015). Fossil fuel $\mathrm{CO}_{2}$ emissions are the most popular goal of such spatial analysis. To obtain more accurate results, the emissions from large point-type sources (especially from fossil fuel combustion in electricity generation) are independently assessed and then added to the total emissions from the diffused sources in each grid cell. A good example of such spatial data is demonstrated by Oda and Maksyutov (2011), who used a point source database and satellite observations of night-time lights as proxy data for estimating diffused emissions. Compiled this way, a global database ODIAC (Opensource Data Inventory for Anthropogenic $\mathrm{CO}_{2}$ ) gives a very good picture of the spatial heterogeneity of human activities with high-resolution of $30^{\prime \prime}$ latitude and longitude grid $(0.9 \times 0.45 \mathrm{~km}$ as for Poland). However, it gives no insight into the origins of emission categories, as the original focus of the development was a global $\mathrm{CO}_{2}$-gridded inventory. Isolations of emissions from industrial processes are possible in the Emission Database for Global Atmospheric Research (EDGAR 2013), which contains annual grid maps with resolution $0.1^{\circ}$ latitude and longitude (emissions of $\mathrm{CO}_{2}$ and other GHGs from fossil fuel combustion in the energy industry, manufacturing industry, fugitive emissions from solid fuels, oil production and refineries, gas production and distribution, metal processes, nonmetallic mineral processes and chemical processes), and some regional studies (Akimoto and Narita 1994; Bun et al. 2007; Boychuk and Bun 2014). A common problem in using the regular grid maps of GHG spatial inventories when change of the grid is required is that these grids often differ not only in grid size but also may be displaced in any direction and/or rotated by a certain angle, see Verstraete (2017) for discussion of the problems connected with map overlay. Another problem is when it is necessary to present the results at the level of administrative units, which causes degradation of inventory accuracy due to round-ups, particularly for small units.

In this study, a new high-definition approach to the spatial analysis of GHG emissions from industrial processes is proposed. As opposed to traditional gridded emissions, it uses direct reference to the point- and area-type emission sources. First, digital maps of emission sources are compiled for all activity categories covered by the IPCC Guidelines (IPCC 2006). Using Google Earth (TM) for point-type emission sources, and the Corine Land Cover (Corine 2006) digital map with a resolution of $100 \mathrm{~m}$ for area-type emission sources, like industrial zones and settlements, we formed maps of emission sources for Polish industry. The activity data for the 
estimation of the emissions at the source level are calculated using statistical data available at the lowest possible level and disaggregation algorithms with proxy data. On this basis, a highdefinition GHG spatial inventory is obtained. Gridded emissions are formed only in the final stage to compute spatial patterns of total emissions from emission sources in different categories. Our novel spatial inventory also enables calculation of the total emissions for the administrative units, even as small as municipalities, without loss of their accuracy. The inventories were compiled for carbon dioxide, methane, nitrous oxide and other GHGs specific for industrial processes, as well as the total emissions in $\mathrm{CO}_{2}$ equivalent. In addition, uncertainties of the obtained results were assessed and their mitigation potential was evaluated both at the emission source and province level according to the IPCC (2001) methodology.

Our multi-resolution modelling approach for multiple GHG emissions is completely new. Gurney et al. (2012) proposed multi-resolution modelling for $\mathrm{CO}_{2}$ emissions from US cities, but modelling all the GHG emissions from all IPCC emission categories is new and it offers a significant advance both in climate mitigation effort monitoring and in science-based assessment of the mitigation effort. Furthermore, our model covers the entire country, which allows us to transfer the knowledge from local to national and then to the global level, which is also completely novel.

\section{Input data}

\subsection{Study area description}

Poland, with an area of $312 \mathrm{~km}^{2}$ and population over 38 million, is a medium-sized country of the EU. Administratively, it is divided into 16 provinces (voivodeships), 380 districts (powiats) and 2478 municipalities (gminas). It is the eighth largest economy in the EU.

The beginning of Polish industry started in the Middle Ages in the Old Polish Industrial Region in the northern part of Lesser Poland (Małopolska). Iron ore, copper and silver were extracted; steel mills were also located there and weapons were manufactured. In the first half of the nineteenth century, there was a rapid development of the region. The growth was stopped in the second half of the nineteenth century but recovered when Poland became an independent state and the Central Industrial Area was established there in the 1930 s.

In the second half of the nineteenth century, the Upper Silesian Industrial Region was developed on the basis of the Upper Silesian Coal Basin. It is now the largest industrial region in Poland, with mining, iron and steel, transport, energy and chemical industries.

Poland's industrial base suffered greatly during the World Wars I and II. During the Soviet-type centralised planned economy, industrialisation of the country was a priority. At that time, new industrial regions and areas were developed, connected with exploitation of newly discovered mineral resources, like the Bełchatów or Konin regions, where large power plants were built to exploit lignite (brown coal), Legnica-Głogów Copper Area, as well as with large agglomerations, like the Warszawa, Łódź, and Wrocław Industrial Regions.

After a change of the political system in the 1990s, the centralised command economy began to be replaced with a market-oriented system. Polish industry underwent a radical restructuration, with the privatisation of small and medium state-owned companies. However, 
many large industrial enterprises, including rail, mining and the defence sector, remained stateowned. An important factor of these structural changes became foreign investment.

Now, the largest component of the Polish economy is the service sector $(\sim 60 \%)$, followed by industry $(\sim 35 \%)$ and agriculture $(\sim 3 \%)$. The mining of coal, which is the main fuel in the production of energy in Poland, is still an important part of the economy. In 2009, Poland was the world's ninth largest hard coal producer, and the second largest coal consumer in Europe behind Germany. A total of $81 \%$ of the electrical energy in 2014 was produced from coal combustion, while only $4 \%$ came from gas and $1 \%$ from oil combustion. The remaining $14 \%$ of electrical energy came from renewables (IEA 2016). The Bełchatów Power Station in the Łódź region is the largest lignite-fuelled power plant in Europe and supplies almost $20 \%$ of Poland's energy. Iron and steel, copper, cement and glass production are other developed sectors. The other main industries include machine building, chemicals and food processing.

A distinguished feature of Polish industry is its high spatial concentration around mining areas, large towns and important transportation areas.

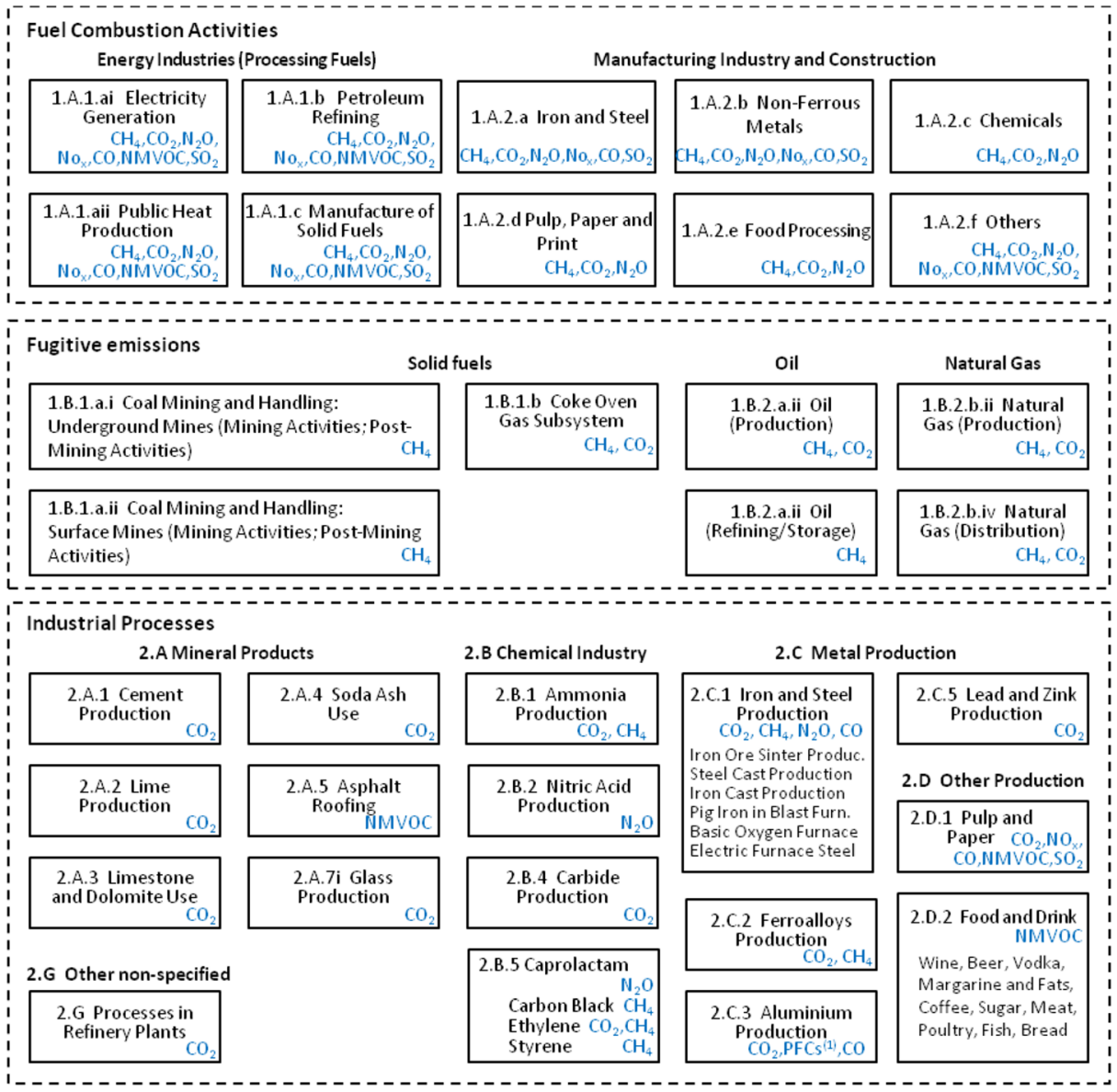

Fig. 1 Emission categories covered by the study, according to IPCC (2006) classification, for different types of GHGs emitted (in blue) 


\subsection{Input datasets: statistical data and high-resolution maps of emission sources}

This study is devoted to all categories of industrial activity covered by IPCC Guidelines (IPCC 2006), see Fig. 1: (1) fuel combustion activities that include electricity and heat production, manufacturing industry and construction, as well as petroleum refining and the manufacturing of solid fuels; (2) fugitive emissions connected with production, storage and distribution of solid fuels, oil, and natural gas; and (3) industrial processes, including the production of mineral products, like cement, lime, limestone, glass and so on, chemical processes connected with the production of ammonia, nitric acid, carbide, and metal production, including iron and steel, ferroalloys, aluminium and so on, as well as the production of pulp and paper, and food and drink.

IPCC Guidelines define the calculation of emissions as multiplication of the activity data for analysed categories by the corresponding emission factors. In this study, we used official statistical data on the economic activities and the emission factors specific for the considered region. Statistical data from GUS (2016) and BDL (2016) were acquired from the lowest possible levels (municipalities, sub-regions and so on) to minimise the data disaggregation depth. Emission coefficients were generally taken from IPCC (2006) and NIR (2012). However, we made an effort to use all available data on regional practices of fossil fuel and raw materials usage. We also used the Corine (2006) Land Cover vector digital map with a resolution of $100 \mathrm{~m}$ and an accuracy of $87.82 \%$ (Büttner et al. 2012). This map was used for the creation of the industrial zones and settlements as polygons that form the elementary emission sources. We also implemented procedures for disaggregation of the activity data to such polygons.

The following input data were used for the calculation of emissions for considered GHG categories:

(a) fuel combustion, with the following activities:

- the categories 'Electricity generation' and 'Public heat production': the map of the power plants as the point-type emission sources and the map of the cities/towns as the area-type emission sources; the electricity and heat production at the national/ provincial levels; the emission coefficients; and the production capacities of the power plants and the numbers of the inhabitants in the cities/towns as the proxy data (GUS 2016; NIR 2012; IPCC 2006; Topylko et al. 2015);

- the category 'Petroleum refining': the map of the refineries as the point-type emission sources; the crude oil refined at the national and provincial levels; the emission coefficients; and the production capacities of the refineries as the proxy data (GUS 2016; NIR 2012; IPCC 2006; Halushchak et al. 2015);

- the category 'Manufacturing of solid fuels': the map of the coke plants as the pointtype emission sources; the coke produced at the national level; the emission coefficients; and the production capacities of the coke plants as the proxy data (GUS 2016; NIR 2012; IPCC 2006; Halushchak 2017);

- the categories 'Iron and steel', 'Non-ferrous metals', 'Chemicals', 'Pulp, paper and print', 'Food processing': the maps of the plants as the point-type emission sources, and the maps of the industrial areas and settlements as the area-type emission sources; the fossil fuels used at the national and provincial levels; the 
emission coefficients (Corine 2006; GUS 2016; NIR 2012; IPCC 2006); the amount of manufactured products; the production capacities; and the gross value added at the sub-provincial level (GUS 2016; BDL 2016; Halushchak et al. 2016) as the proxy data;

(b) fugitive emissions:

- the category 'Coal mining and handling: mining and post-mining activities': the map of the mines as the point-type emission sources; the coal produced at the national and provincial levels; the emission coefficients; the production capacities as the proxy data (GUS 2016; BDL 2016; NIR 2012; IPCC 2006; Halushchak 2017);

- the category 'Coke oven gas subsystem': the map of the coke plants as the point-type emission sources; the coke produced at the national level; the emission coefficients; and the production capacities of the coke plants as the proxy data (GUS 2016; BDL 2016; NIR 2012; IPCC 2006; Halushchak 2017);

- the categories 'Oil (production, refining/storage)' and 'Natural gas (production, distribution)': the map of the oil and natural gas production fields, and the refineries as the point-type emission sources; the oil and natural gas produced at the national level; the emission coefficients; and the production capacities as the proxy data (GUS 2016; BDL 2016; NIR 2012; IPCC 2006; Halushchak et al. 2015);

(c) industrial processes:

- the subsector 'Mineral products': the maps of the cement, lime, glass and other plants as the point-type emission sources; the production at the national and provincial levels; the emission coefficients; and the production capacities as the proxy data (GUS 2016; BDL 2016; NIR 2012; IPCC 2006; Charkovska et al. 2012; Charkovska et al. 2015b);

- the categories 'Ammonia production', 'Nitric acid production', 'Carbide production', and 'Caprolactam': the maps of the plants as the point-type emission sources; the production at the national and provincial level; the emission coefficients; and the production capacities as the proxy data (GUS 2016; BDL 2016; NIR 2012; IPCC 2006; Charkovska 2015a);

- the subsector 'Metal production': the maps of the plants for production of the iron and steel, ferroalloys, aluminium, lead and zinc as the point-type emission sources; the production at the national and provincial levels; the emission coefficients; and the production capacities as the proxy data (GUS 2016; BDL 2016; NIR 2012; IPCC 2006; Charkovska et al. 2015c);

- the categories 'Pulp and paper' and 'Processes in refinery plants': the map of the plants for pulp and paper production, and the map of the refineries as the point-type emission sources; the production at the national and provincial levels; the emission coefficients; and the production capacities as the proxy data (GUS 2016; BDL 2016; NIR 2012; IPCC 2006; Charkovska et al. 2015c);

- the category 'Food and drink': the map of the settlements as the area-type emission sources; the production at the provincial levels; the emission coefficients; and the numbers of inhabitants as the proxy data (BDL 2016; NIR 2012; IPCC 2006; Charkovska 2015a). 


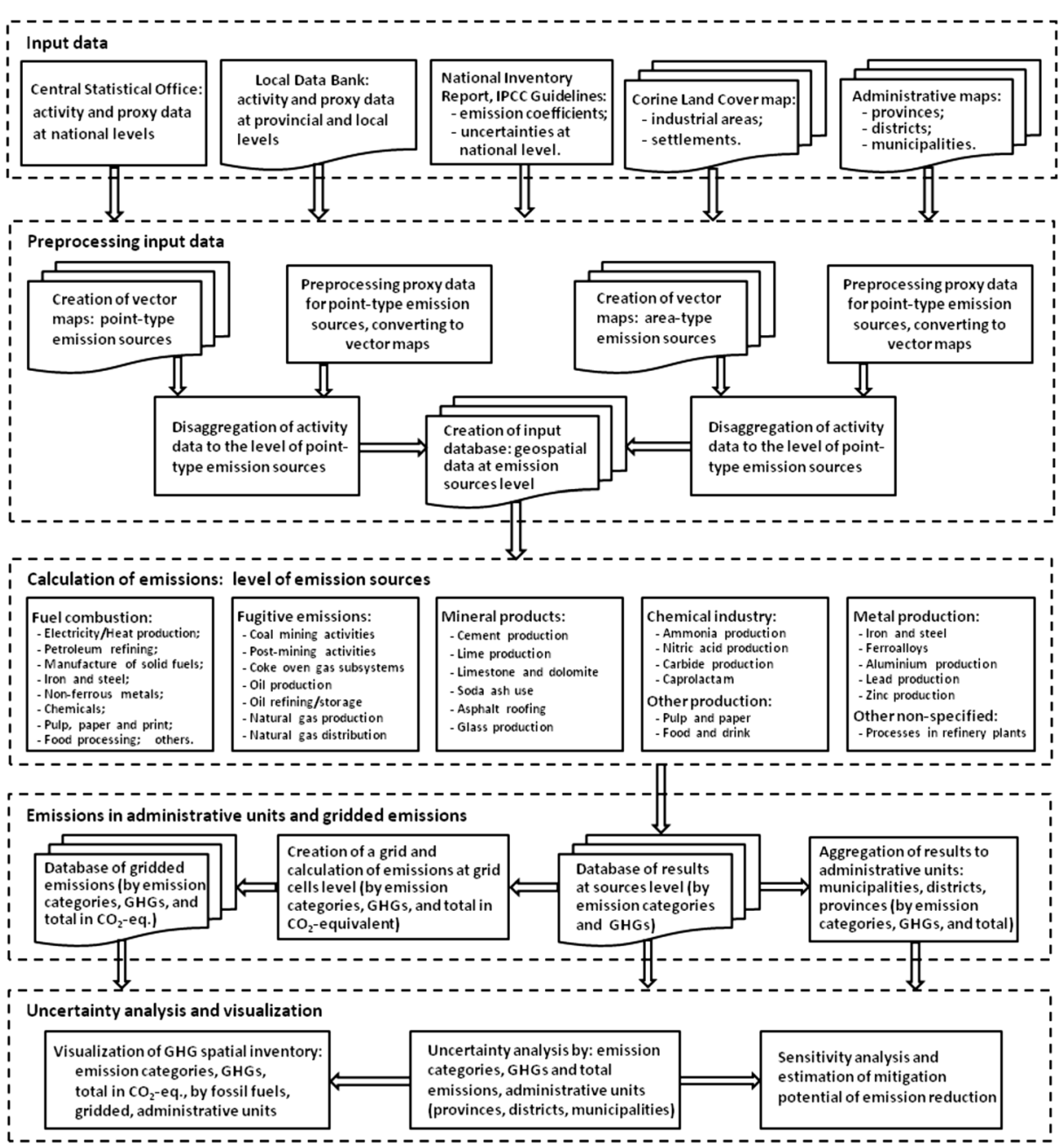

Fig. 2 Flow chart of the geoinformation technology method for the high-definition spatial inventory of GHGs for industry

\section{Research methods}

\subsection{Emission sources and proxy data used}

The method of compiling the high-definition spatial inventory of GHGs for the industrial processes with the use of our geoinformation technology is explained in the flow chart in Fig. 2. The flow chart presents our general idea of the emission spatial analysis directly at the emission source level. It differs completely from the traditional approach of compiling the gridded emissions, where analysis is conducted at the regular grid cell level. In our approach, the regular cells are introduced only when the total emissions for all sources have been calculated.

Taking this into account, we focused on a thorough preparation of the emission source maps. Many of the industrial emission sources can be treated as point-type ones, including the 


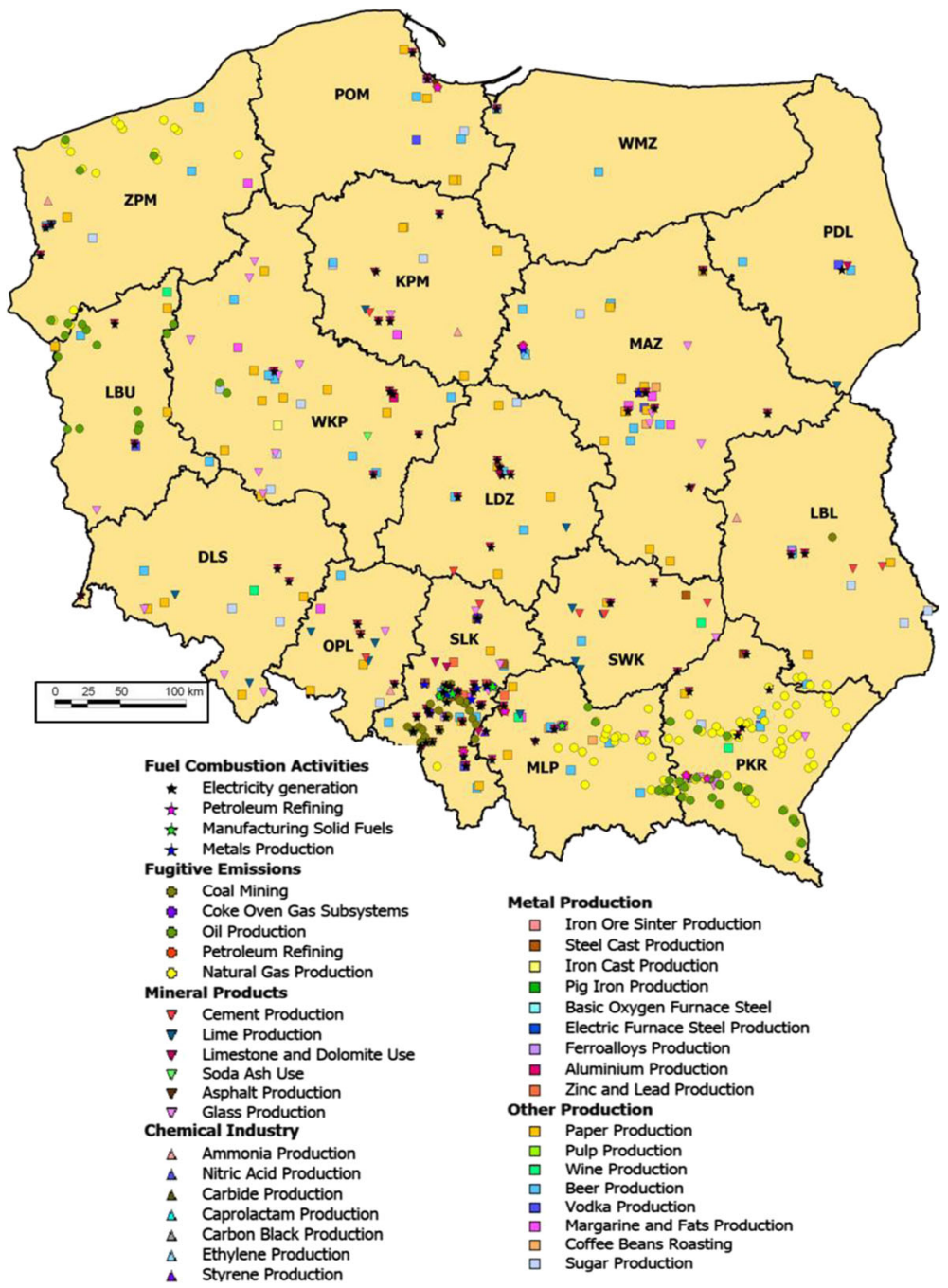

Fig. 3 Map of point-type sources of GHG emissions from industrial processes

power plants, the coal mines and the coke plants, the oil and natural gas production fields/ wells, the refineries, the plants for production of cement, iron and steel, ferroalloys and nonferrous metals, aluminium, lead and zinc, pulp and paper, lime, glass, ammonia, nitric acid, carbide, caprolactam and other chemicals (Fig. 3). The horizontal dimensions of these kinds of sources (stacks) are small in comparison with the analysed areas. We assembled latitudes and longitudes of all these sources and for all categories in Poland using Google Earth and compiled vector maps for them.

It is practically impossible to consider smaller industrial sources, particularly in the manufacturing industry and food/drink processing, as point-type objects. Hence, we model them as areal (diffused) objects in identified industrial areas or settlements, using the polygons of the Corine Land Cover (Corine 2006) map. Each category has, however, its specificity that is discussed in the sequel. 
Pre-processing of the input data includes creation of the vector maps for the point- and areatype emission sources for the investigated categories; pre-processing of the proxy data (production capacities of the mines, refineries, plants, the gross value added, the number of the inhabitants and so on) and converting them to the vector maps; and disaggregation of the activity data to the emission source level. We elaborated disaggregation algorithms for the activity data and mathematical models and algorithms for calculation of the elementary source emissions for the point- and area-types using the activity data and the emission factors. In the compiled geospatial database of the emission sources, we omitted the categories that do not exist in the Polish economy and the categories for which emissions cannot be assessed in Poland, for example in emission categories 'Consumption of halocarbons' or 'Solvent and other product use'. All these data are stored directly in a database.

Dependent on the task at hand, we finally create grid cells to combine the calculated GHG emissions from diverse sources/categories into a geospatial database of the total emissions from the industrial processes. These grid cells are also elements/polygons of the vector map. Therefore, it is possible to split the grid cells into smaller irregular elements, for example, when any administrative border crosses the cell. Generally, the grid size depends on the task solved but cannot be smaller than $100 \mathrm{~m}$, which is the resolution of the input land cover map. Our results can be also easily aggregated to administrative units, theoretically without any loss of accuracy, because we deal with the vector maps (some inaccuracies may happen in the case of multi-stock emission sources, see discussion in the sequel).

\subsection{Fuel combustion activities}

Since the data on fossil fuel combustion are available at the national level only (provincial level for some categories), we created mathematical models and algorithms for disaggregation of these data to the level of cities and industrial objects, using other statistical data as proxy (especially the production capacities, the gross value added, the area of industrial objects/ territories, the number of the inhabitants in the cities and so on).

The emission of the gth GHG from the fuel combustion of the $i$ th elementary object (the point- or area-type emission source) in the energy and manufacturing industry can be calculated using a common formula:

$$
E_{\text {Ind }, g, i}=\sum_{\text {Ind }} \sum_{f \in F} A_{\text {Ind }, f} \times D_{\text {Ind }, f, i} \times C_{f, i} \times F_{g, f, i},
$$

where $g \in\left\{\mathrm{CO}_{2}, \mathrm{CH}_{4}, \mathrm{~N}_{2} \mathrm{O}, \ldots\right\}$ is the GHG type; Ind $\in$ \{electricity generation, manufacturing solid fuel, petroleum refining, metallurgy, chemicals, food processing, and others $\}$ is the emission category in the energy and manufacturing industry; $A_{\text {Ind, } f}$ is the amount of the $f$ th type fossil fuel used in the emission category under investigation, $f \in$ \{solid fuel, liquid fuel, gaseous fuel, biomass $\} ; D_{\text {Ind, } f, i}$ is the disaggregation coefficient, which depends on the emission category (see Appendix); $C_{f, i}$ is the calorific value of the $f$ th type fuel for the $i$ th source; and $F_{g, f, i}$ is the emission factor of the $g$ th GHG for the $f$ th fossil fuel and the $i$ th emission source.

The disaggregation coefficients depend on the category of industrial activity, because different statistical data are available for different categories. In some categories, we used the point-type emission sources to model emission processes from the large plants (metallurgy, chemicals and so on), but in other cases of smaller industrial activity, we used the area-type emission sources, as it is impossible to acquire all necessary data for each small enterprise. The 
land cover digital map of Poland was used to identify the industrial zones (the areas with industrial activity).

Therefore, the main approach to the disaggregation of the activity data (the statistical data on the fossil fuel combustion) in the industry sector consists of the following steps (we apply these steps using created software modules for the geoinformation technology, illustrated in Fig. 2):

1) The available data on the fuel consumed in the large point-type emission sources or the data calculated using the production capacities as proxy data are directly used for calculating the emissions from these sources;

2) The residual fossil fuels are disaggregated from the national level (if possible from the provincial level) to the district level using the data on the gross value added as a proxy;

3) The calculated data on the fossil fuel combustion at the district level are disaggregated to the level of industrial zones or settlements using the available data on the area and the number of inhabitants as a proxy.

\subsubsection{Emissions from metallurgy industry}

Assessment of the GHG emissions in the metallurgy industry is important, because this kind of anthropogenic activity includes technological processes with energy-intensive and raw material-intensive production. In Poland, there are 22 steelworks, including 10 large ones, producing $\sim 80 \%$ of all steel products. The largest corporation, ArselorMittal, includes four major metallurgy plants-Huta Cedler (which is within the 70 largest steelworks in the world), Huta Florian, Huta Sendzimir and Huta Katowice. For assessment of GHG emissions in this sector, we identified the locations of the steelworks as the point-type emission sources using the Google Earth. On the basis of these locations, we marked the corresponding industrial zones as the area-type emission sources in the land cover digital map and calculated GHG emissions according to the amount of production (sales) at each metallurgical plant as a proxy (see Appendix).

\subsubsection{Emissions from chemical industry}

The chemical industry in Poland is one of the most innovative, but at the same time, most environmentally dangerous sectors of the economy. The largest sources of GHG emissions from the chemical industry of Poland are the Puławy nitrate fertiliser plant in the Lublin Province (Zakłady Azotowe Puławy), Anwil SA in the Kuyavian-Pomeranian Province and ZAK SA in the Opole Province. Anwil SA produces ethylene-based products as intermediate raw materials for the production of polyamide threads and plastic construction elements (caprolactam), ammonium sulphate and non-organic products (sulphuric acid, chlorine and sodium hydroxide). The Puławy nitrate fertiliser plant and ZAK SA produce nitrogen fertilisers, plasticisers, oxo alcohols and other chemicals.

In contrast to the metal industry, the number of chemical plants is much greater. The production capacities of the 14 largest plants are known, but there are many other plants with unknown capacities. We disaggregated the fuel use to the level of the province and sub-regions according to the data on the gross value added in the chemical industry. As the share of the fossil fuels used by the largest 14 factories was known, we assumed that the remaining fuel was combusted in the industrial areas 
(since emissions from the chemical industry are quite unhealthy, most plants are located outside cities). Finally, for the industrial areas (other than those where the largest plants are located), we disaggregated the data on the fuel use within the sub-regions using the zone area as a proxy.

\subsubsection{Emissions from food processing industry}

For this category of anthropogenic activity, we assumed that the consumed fossil fuel is spatially distributed in proportion to the number of inhabitants in the settlements (see Appendix). We took only settlements with more than 1000 inhabitants into account because this industry is mainly located close to large number of consumers. In small rural villages, there is less need for industrial food processing.

\subsection{Fugitive emissions}

\subsubsection{Mining processes}

Mines are assumed to be point-type emission sources. For spatial inventory of the fugitive emissions of the $g$ th GHG from the $i$ th mine, we used the formula $E_{\mathrm{coal}, g, i}=E_{\mathrm{coal}, m, g, i}+E_{\mathrm{coal}, p, g, i}$, where $E_{\mathrm{coal}, m, g, i}$ and $E_{\mathrm{coal}, p, g, i}$ are the annual emissions from the mining and post-mining processes, $g \in\left(\mathrm{CO}_{2}, \mathrm{CH}_{4}\right)$ :

$$
E_{\mathrm{coal}, m, g, i}=\frac{A_{\mathrm{coal}}^{\Sigma} \times P_{\mathrm{coal}, i}}{\sum_{j=1}^{J} P_{\mathrm{coal}, j}} \times K_{\mathrm{coal}, m, g, i}, E_{\mathrm{coal}, p, g, i}=\frac{A_{\mathrm{coal}}^{\Sigma} \times P_{\mathrm{coal}, i}}{\sum_{j=1}^{J} P_{\mathrm{coal}, j}} \times K_{\mathrm{coal}, p, g, i},
$$

where $A_{\text {coal }}^{\Sigma}$ is the annual mining of the coal in Poland, $P_{\text {coal }, i}$ is the annual capacity of the $i$ th mine; $K_{\text {coal, } m, g, i}$ and $K_{\text {coal, } p, g, i}$ are the emission factors for the mining and post-mining processes, respectively.

\subsubsection{Oil production and refining}

To perform GHG spatial inventory for this sector, we assembled a map of the oil production fields/wells and a map of the refineries in Poland. We assumed that the emission sources are of the point-type. As the proxy data, we used the data on the oil production capacities of the fields/wells and the production capacities of the refineries. To compile the spatial inventory of the fugitive emissions of GHG from the oil production $E_{\mathrm{oil}, p, g, i}$ and the refining/storage, we used the formulas:

$$
E_{\mathrm{oil}, p, g, i}=\frac{A_{\mathrm{oil}, p}^{\Sigma} \times P_{\mathrm{oil}, p, i}}{\sum_{j=1}^{N} P_{\mathrm{oil}, p, j}} \times K_{\mathrm{oil}, p, g, i}, E_{\mathrm{oil}, r, g, i}=\frac{A_{\mathrm{oil}, r}^{\Sigma} \times P_{\mathrm{oil}, r, i}}{\sum_{j=1}^{N} P_{\mathrm{oil}, r, j}} \times K_{\mathrm{oil}, r, g, i}, g \in\left(C \mathrm{O}_{2}, C H_{4}\right),
$$

where $E_{\mathrm{oil}, p, g, i}$ and $E_{\mathrm{oil}, r, g, i}$ are the annual emissions of the $g$ th GHG at the $i$ th oil production field or refinery; $A_{\mathrm{oil}, p}^{\Sigma}$ and $A_{\mathrm{oil}, r}^{\Sigma}$ are the total annual production and refining of the oil in Poland, respectively; $P_{\mathrm{oil}, p, i}$ is the oil production capacity of the $i$ th field/well; $P_{\mathrm{oil}, r, i}$ is the capacity of the $i$ th refinery; and $K_{\mathrm{oil}, p, g, i}$ and $K_{\mathrm{oil}, r, g, i}$ are the emission factors of the $g$ th GHG at the $i$ th oil production field/well or at the $i$ th refinery, respectively. 


\subsubsection{Natural gas production and distribution}

In this sector, we formed a map of production fields/wells in Poland. We assumed that the emission sources are of the point-type for the production activity and the area-type for the distribution processes in settlements. As the proxy data for the production activity, we used the data on the natural gas production capacities of the fields/wells, and for the distribution processes, we used the population data and the data on the natural gas consumption at the provincial level.

\subsection{Industrial processes}

\subsubsection{Cement production}

Most emissions from the cement industry are caused by the clinker production as an intermediate mineral in the cement production process (IPCC 2006). The Polish cement industry is widely developed in seven of the 16 provinces. There are 11 cement production plants with a full production cycle, one cement grinding plant and one alumina cement production plant. The full production cycle comprises all stages of cement production, in particular, the processes of clinker calcination and cement grinding (IPCC 2006). The largest cement producers are Górażdże Cement S.A. (concern Heidelberg), Lafarge Cement S.A. (concern Lafarge) and Grupa Ożarów S.A. (concern CRH). The shares of these groups in the national cement production are $26 \%, 21 \%$ and $17 \%$, respectively. We created a map of cement plants as the point-type emission sources, formed a set of the input geospatial data and compiled GHG spatial inventory in the cement production category in Poland using the formula presented in the Appendix.

\subsubsection{Other industrial processes}

We performed similar spatial inventories for other categories of economic activity of the industrial sector, which are characterised by a significant level of emissions, including the mineral products (lime production, limestone and dolomite use, soda ash use, asphalt roofing and glass production), the chemical industry (production of the ammonia, nitric acid, carbide and caprolactam and so on), metal production (production of the iron and steel, ferroalloys, aluminium, lead and zinc), pulp and paper production and some categories of food and drink production.

\section{Results}

\subsection{Level of emission sources}

We used the prepared input data, maps, disaggregation algorithms of the activity/proxy data and models of the emission processes to compile GHG spatial emissions on the source level for Poland in 2010 (see the results in Supplementary Materials). They include emissions of carbon dioxide, methane, nitrous oxide and other GHGs from all categories of industrial processes that are presented in Fig. 1, and for all point- and area-type emission sources depicted in Figs. 3 and 4. 


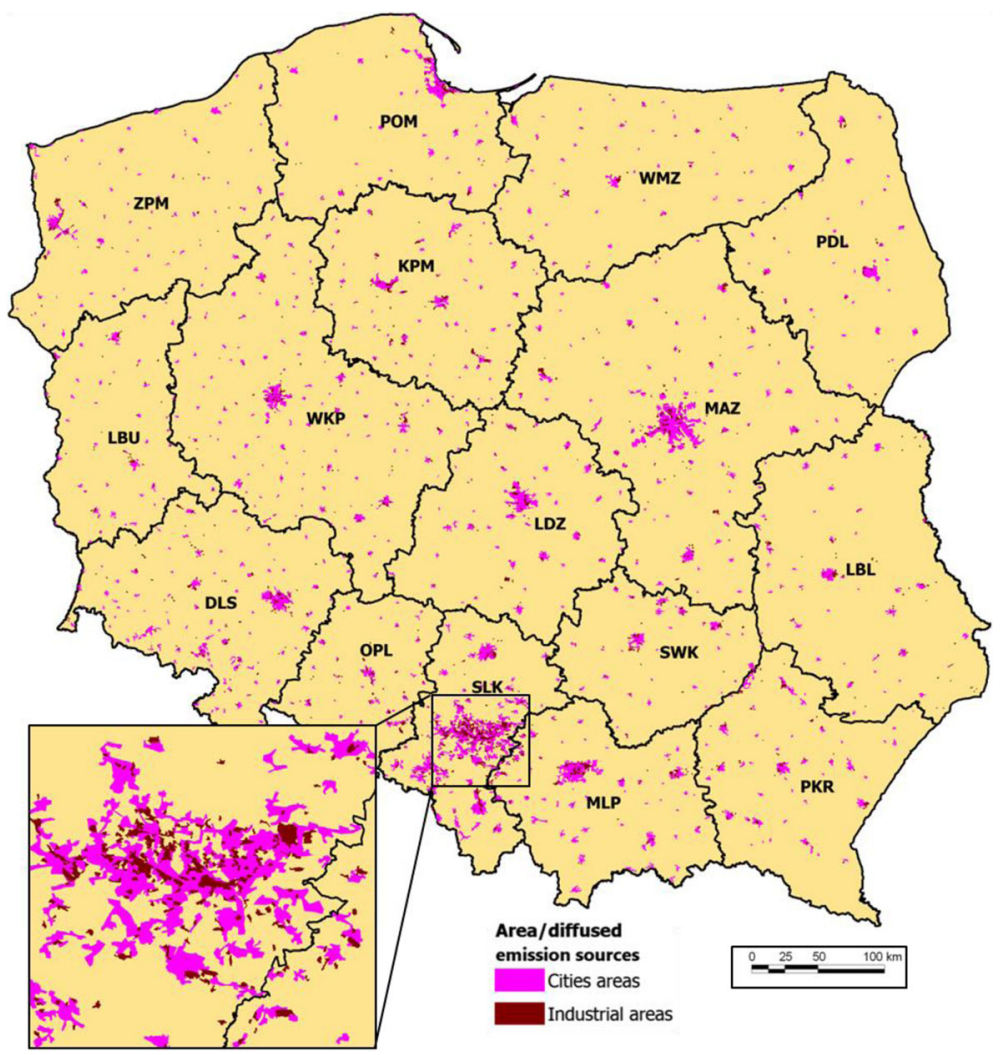

Fig. 4 Map of area-type sources of GHG emissions from industrial processes

\subsection{Total emissions}

For further use, we aggregated the total emissions from all different emission sources mentioned above in a regular $0.5^{\prime} \times 0.5^{\prime}$ longitude and latitude grid, which has the cell size of order $1.0 \times 0.5 \mathrm{~km}$ for Poland. The same grid was used in the ODIAC global gridded data on GHG emissions (Oda and Maksyutov 2011, 2015). Instead of a traditional raster map, we used our vector map with polygon objects that were cut into smaller areas when a cell boundary crossed a polygon. Calculated this way, the total emissions from all categories of industrial processes in Poland are depicted in Fig. 5, where it can be noticed that the industrial emissions are localised only in the towns and industrial areas. Emissions in these areas are very high, particularly those related to the point-type emission sources, which are poorly visible in the figure.

Figure 6 visualises the emissions from the largest agglomerations of Warszawa, Gdańsk, Łódź, Kraków and Katowice, in 3D prism form. Here, the emissions from point-type sources are clearly visible. Differences in the magnitudes of these emissions are so high that the square root function was used to scale them. Figure 6 clearly shows how much the point-type emission sources influence the spatial distribution of the emissions.

The spatial inventory of GHG emissions at the emission source level gives the possibility to aggregate the emissions to the administrative units of different levels (municipalities, districts or provinces). Figure 7 depicts GHG total emissions from all categories of the industrial 


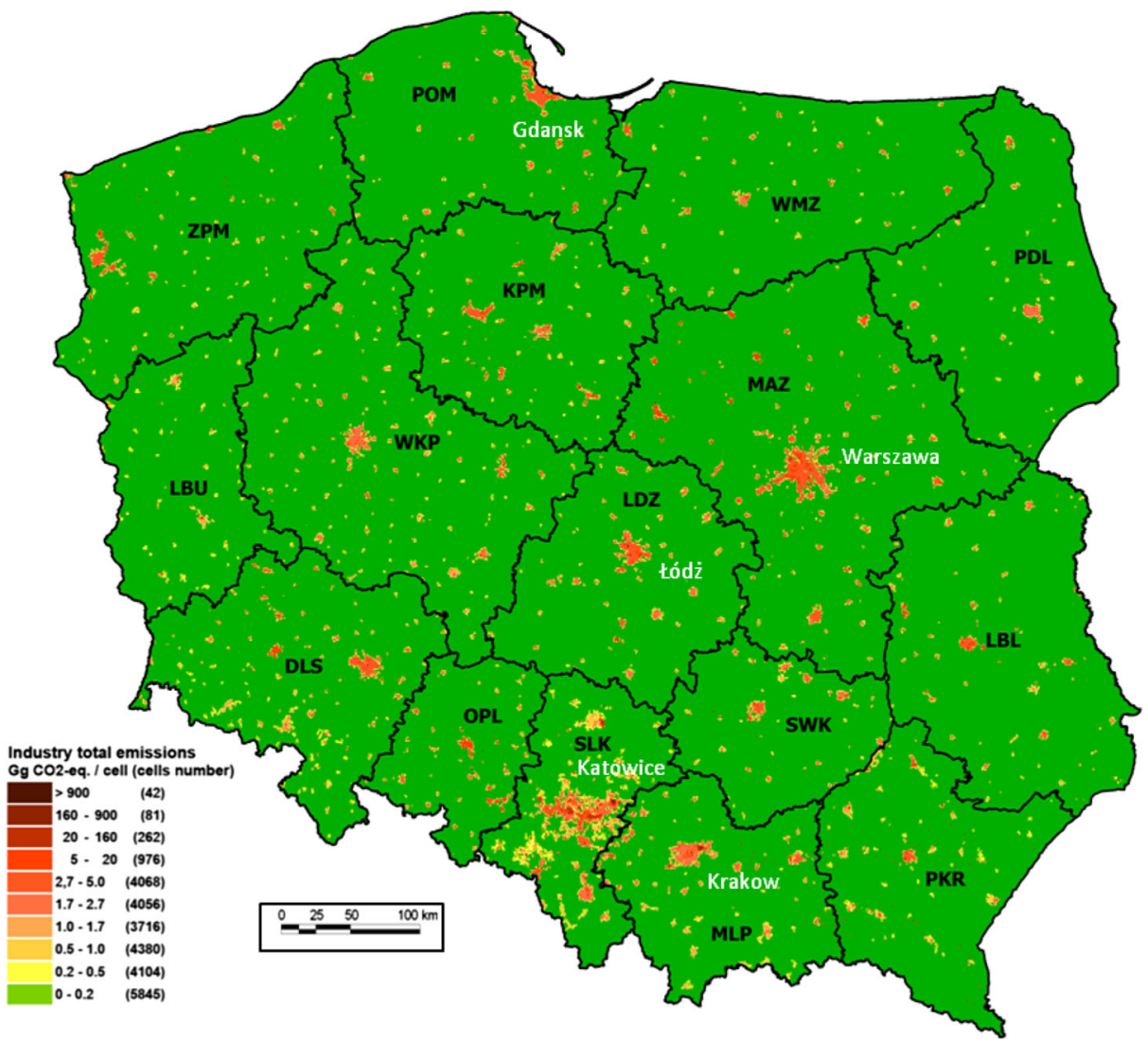

Fig. 5 GHG total emissions from all categories of industrial processes in Poland, with a grid of $0.5^{\prime} \times 0.5^{\prime}$ latitude and longitude $(\approx 1.0 \times 0.5 \mathrm{~km}), \mathrm{Gg} \mathrm{CO}$-eq., 2010

processes in Poland at the provincial level. The emissions from electricity generation are distinguished, because these emissions are the highest from all industrial processes. The emissions of methane and nitrous oxide from the subsectors of the industrial processes (see Fig. 8) are much smaller.

\subsection{Uncertainty analysis}

Input data, which are used in our mathematical models for GHG spatial inventory, are subject to uncertainties (Ometto et al. 2015; White et al. 2011) that reflect the lack of our knowledge regarding emission processes. Hence, estimation of the GHG inventory uncertainty should be an integral part of the spatial modelling of GHG emissions. Uncertainty has a significant destabilising effect in the practical implementation of international agreements and in setting targets for reducing GHG emissions in the short and long terms. Uncertainty is not constant since it changes over time as a result of our 'learning' (improving our knowledge of the emission processes and the way of compilation of the final inventory reports) and due to structural changes of the emissions (such as changes in the structure of consumption of the fossil fuels, introduction of low carbon technologies and so on) (Jonas and Żebrowski 2019; Jarnicka and Żebrowski 2019). In the spatial analysis of the emission processes, the situation is 

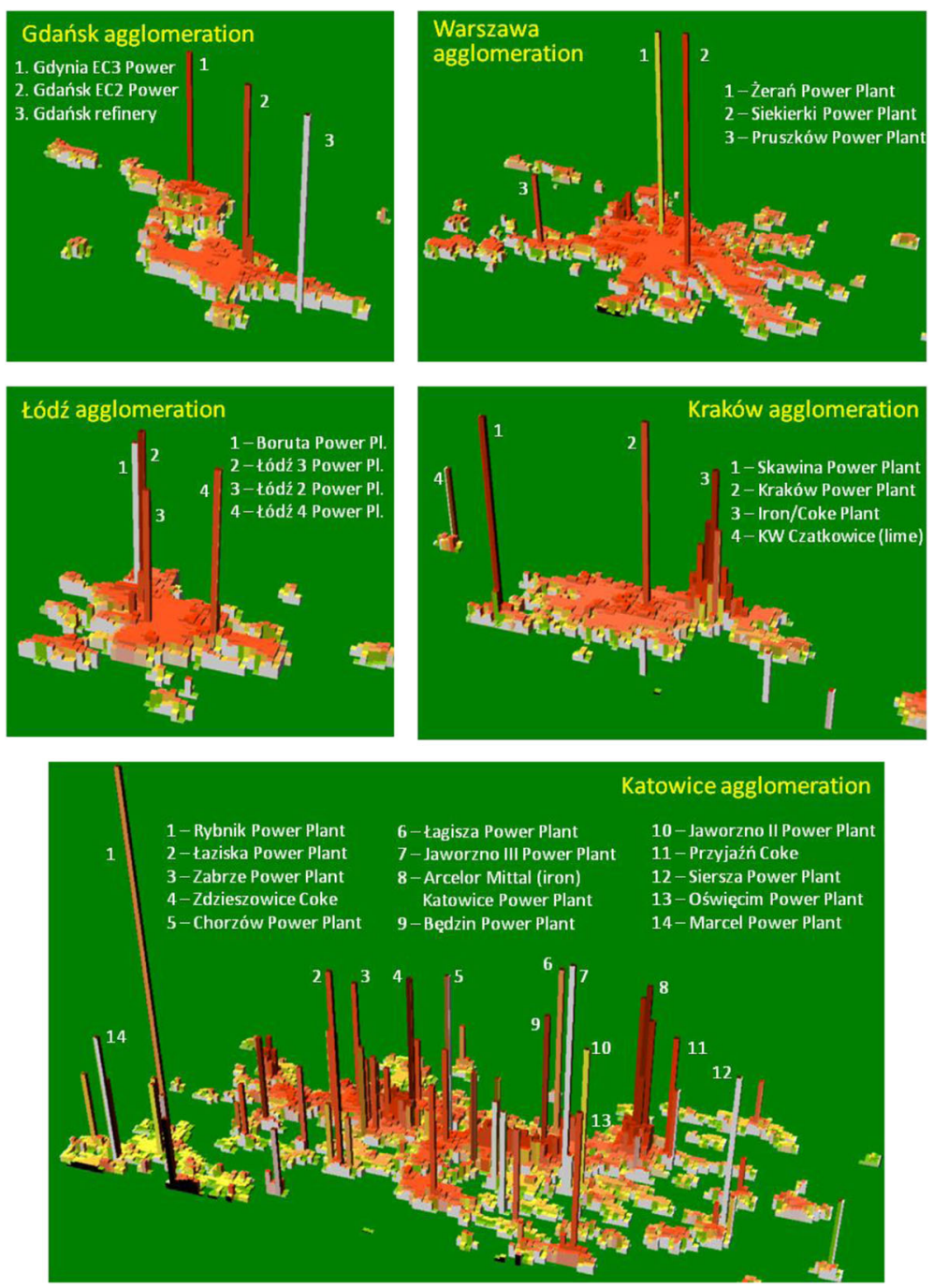

Fig. $63 \mathrm{D}$ prism maps of GHG total emissions from all categories of industrial processes in the main agglomerations of Poland, with a grid of $0.5^{\prime} \times 0.5^{\prime}$ longitude and latitude $(\approx 1.0 \times 0.5 \mathrm{~km}), \mathrm{Gg} \mathrm{CO}_{2}$-eq., 2010 , square root scale

much more complicated, because in this case, the total uncertainty depends on the uncertainties of the emission source and sink geolocations, the uncertainties of the aggregated activity data, the uncertainty of the proxy data representation (the uncertainty of the spatial disaggregation of the activity data), the uncertainty of the proxy data values, the uncertainty of the proxy data geolocation and the uncertainty of the emission factors (Hogue et al. 2016, 2019; Bun et al. 2019; Zheng et al. 2017).

One of the most important factors influencing the spatial analysis uncertainty is misplacement of the emission sources due to errors in their coordination assessment. This question is discussed in the sequel on examples from spatial inventory for Poland. In our method of accurate location of high-emitting stacks, this error is small at the emission source level of modelling. The situation is more complicated in the case of the gridded emissions. Even with 


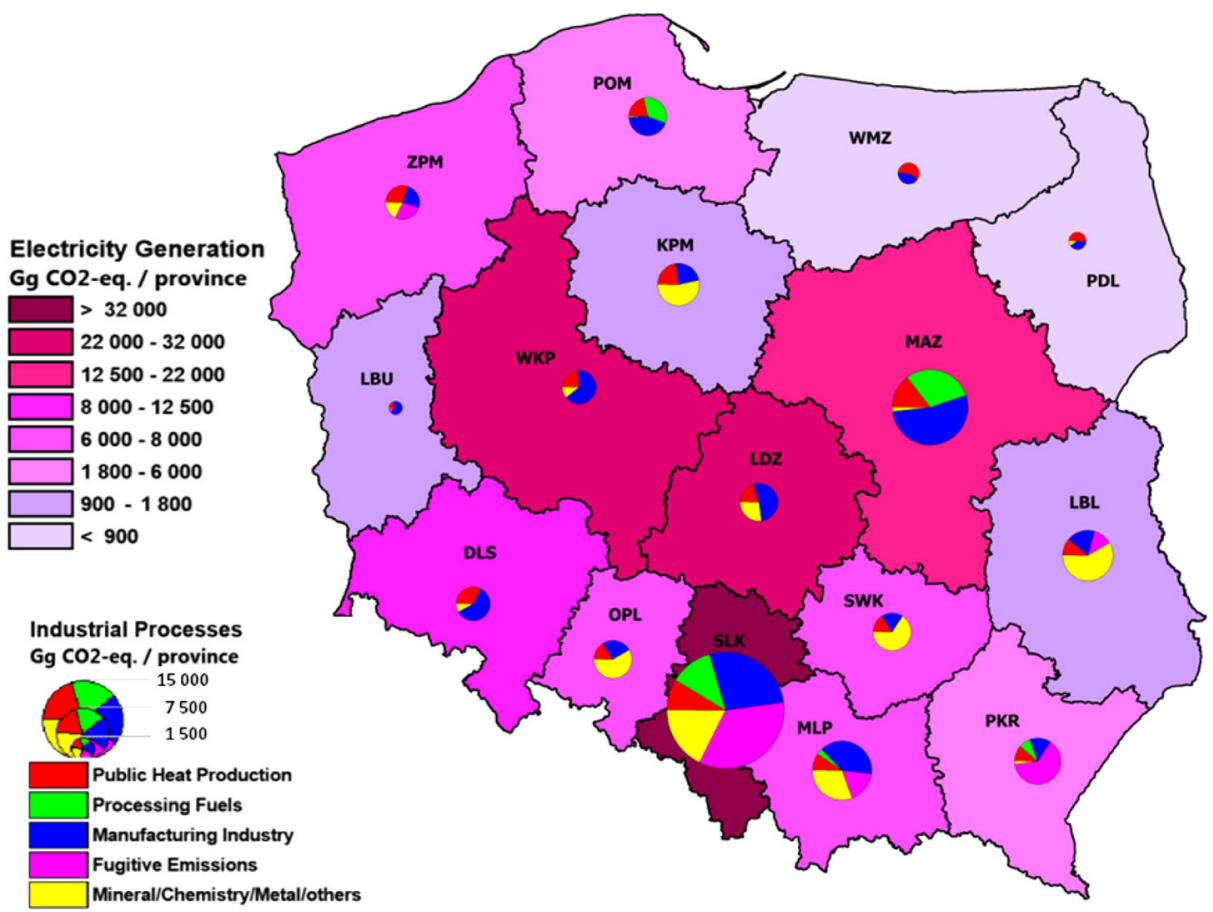

Fig. 7 GHG total emissions from all categories of industrial processes in Poland at the provincial level (electricity generation and other subsectors of the industrial processes are presented separately, $\mathrm{Gg}_{\mathrm{CO}}$-eq., 2010, square root scale)

small location errors, a source may be misallocated to a neighbouring cell. In such a case, the absolute misallocation error is smaller for fine grids, but the relative errors are greater. There is also a higher probability of misallocation occurrence. For further discussion of this question, see Hogue et al. $(2016,2019)$ and Hutchins et al. (2017).

There are good and well-founded methods for accurate accounting of the economic activity (the production volumes). However, sufficient scientifically grounded methods for the estimation of emission coefficients are not always known. It is usually assumed that the input statistics, activity and proxy data used in the emission models and the specific plants' GHG emission factors are random variables.

Uncertainty analysis of the activity data in the Polish industrial sector is fully carried out during preparation of the NIRs on GHG emissions. According to these estimates, the relative uncertainty of the statistical data for various industrial emission processes at the country level is in the range of $2-5 \%$ (NIR 2012), with a normal distribution and $95 \%$ confidence interval. This range is typical for the energy industries, manufacturing industries and construction, fugitive emissions from coal mining and handling, cement and metal production and chemical industry. However, there are some categories with smaller activity data uncertainties $(0.5 \%$ for oil production and refining, as well as for natural gas production and distribution), and some categories with higher uncertainties, like lime or soda ash production (10\%).

At the emission category level, the most accurate evaluations of the emission factors for carbon dioxide are for gaseous fuels in the energy industry and liquid fuels in the manufacturing industry (1\%), liquid fuels in the energy industry and solid and gaseous fuels in the 


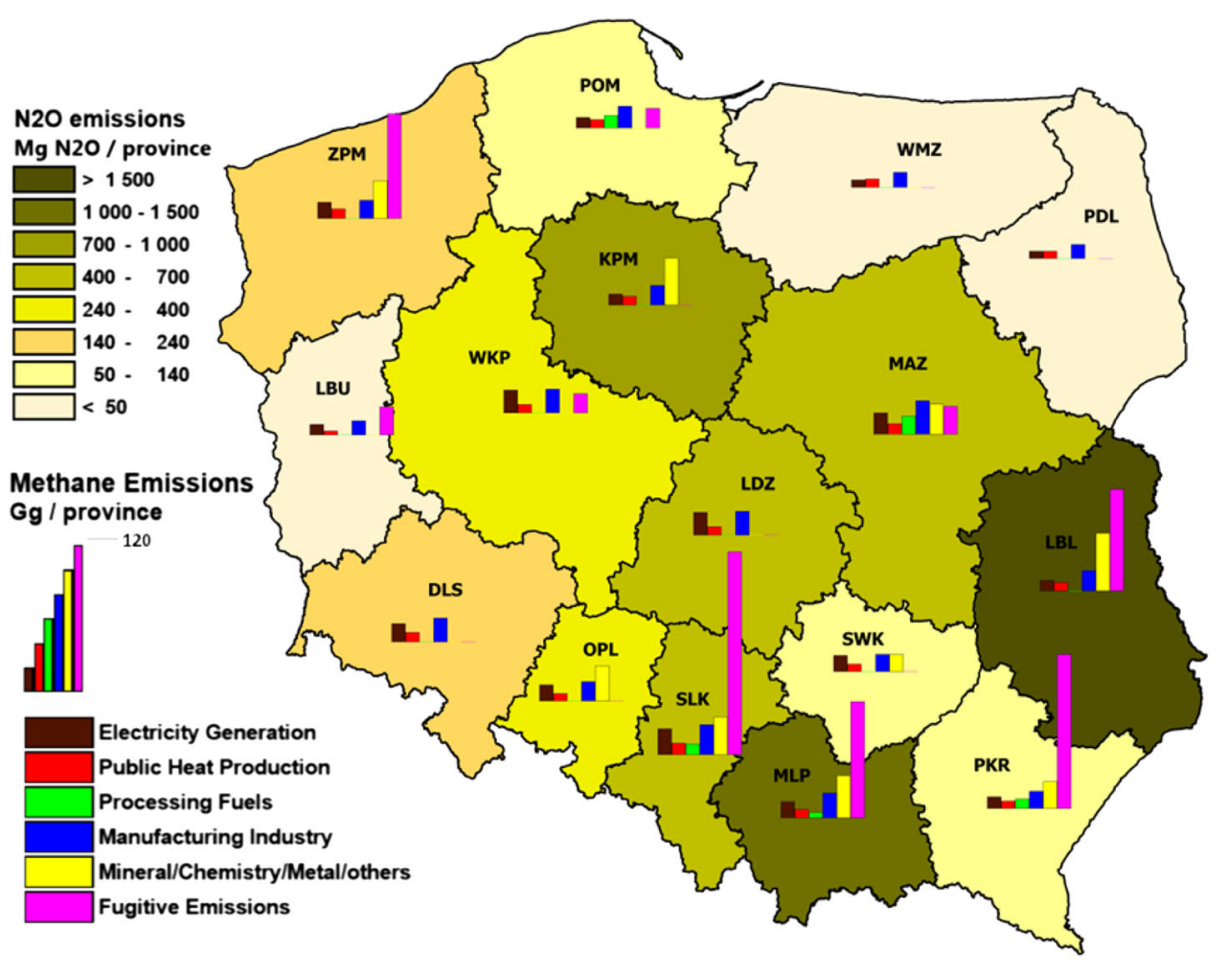

Fig. 8 The total emissions of methane $(\mathrm{Gg})$ and nitrous oxide $(\mathrm{Mg})$ from all subsectors of industrial processes in Poland at the provincial level (2010; for the methane, the scale is raised to the power of 0.3 )

manufacturing industry (2\%), and solid fuels in the energy industry (3\%) (NIR 2012). For most categories, the $\mathrm{CO}_{2}$ emission factor uncertainties are in the range of 5-10\% (fugitive emissions, chemical industry and metal production), and the highest is for cement production (15\%) (see Charkovska et al. 2015c). The uncertainty of the methane emission factor for most sources in the industrial process sector is $20 \%$. The smaller emission factor uncertainties for methane are for liquid (13.5\%) and gaseous (17\%) fuels in the energy and manufacturing industry, and for the fugitive emissions from oil and natural gas production $(8.1 \%)$. The highest emission factor uncertainties for methane are for liquid fuels in the energy industry (75\%), and the fugitive emissions for coal mining and handling (50\%).

To assess GHG emission uncertainty, the Monte Carlo method is often applied. Using information on the input parameter uncertainties, estimates of the GHG emission uncertainties for different enterprises, regions and the country as a whole, can be calculated this way. On the basis of the created geospatial data and the developed approach to the uncertainty analysis of GHG emissions, we performed computational experiments to assess emission uncertainties for the production of electricity and heat, cement, lime, nitric acid, ammonia, iron and agglomerates, fugitive emissions and for other categories of industrial processes in Poland, applying the Monte Carlo method and using the activity data for 2010 at the provincial level (see Fig. 9). Symmetric (normal) and asymmetric (log-normal) distributions of the analysed parameters, as well as a $95 \%$ confidential interval, were used in these calculations.

We used our GHG spatial inventory results and the data on the relative uncertainties of the activities and the emission factors published in NIR (2012) for separate categories of the industrial processes (symmetric distribution; 95\% confidential intervals) as the input data in 


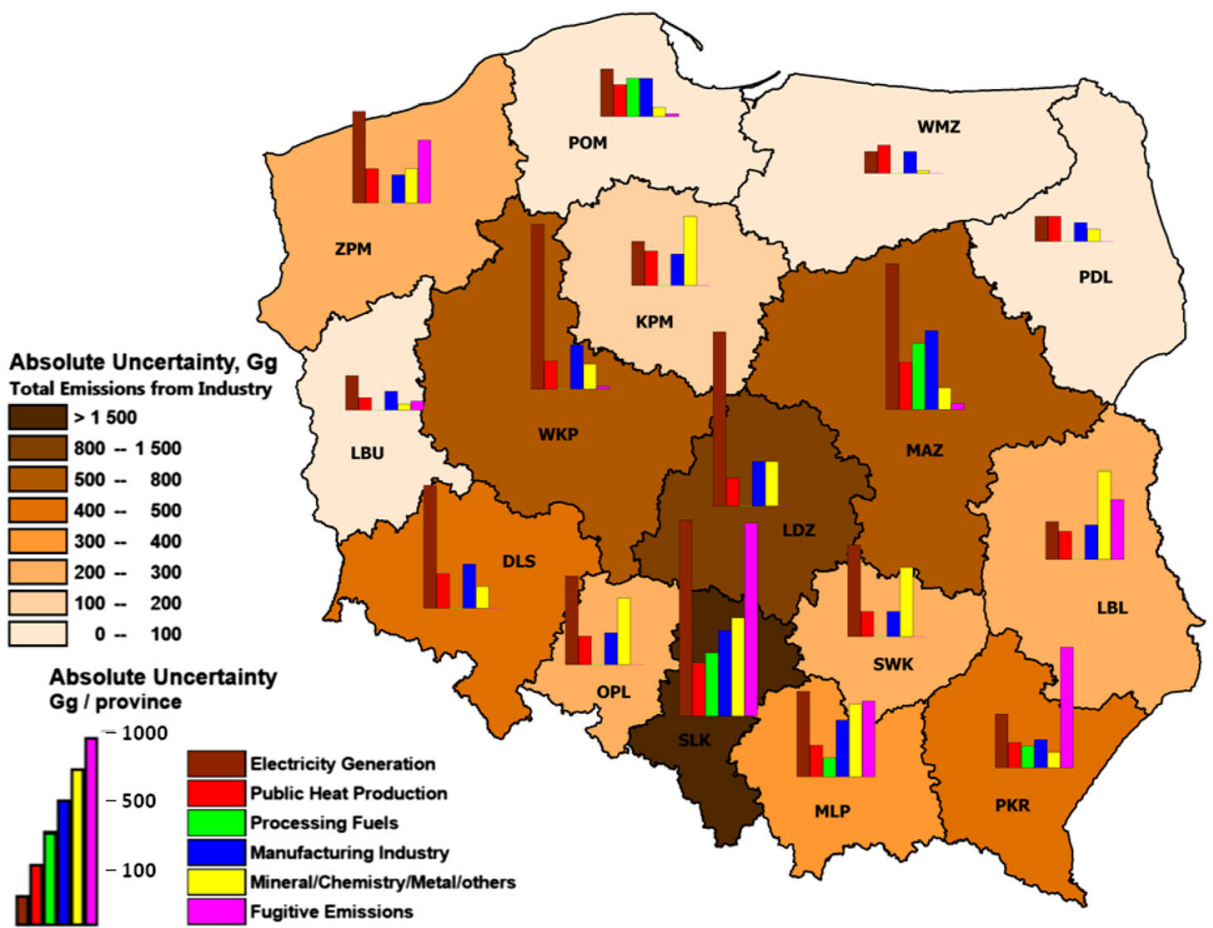

Fig. 9 The absolute uncertainties of GHG emissions from industrial processes at the provincial level $\left(\mathrm{Gg} \mathrm{CO}_{2}\right.$ equivalent, 2010): for the total emissions (upper legend) and for the main subsectors (lower legend; square root scale)

these calculations. The absolute uncertainties presented in Fig. 9 demonstrate the contribution of each subsector to the absolute uncertainty of emissions from the industrial processes.

\section{Discussion}

\subsection{Methods}

According to our assumptions, all sources of GHG emissions from industrial processes are modelled as point- or area-type sources. The created vector digital maps of the point-type emission sources for each category under consideration include the industrial objects with significant GHG emissions, concentrated in small physical areas. Many small emission sources located in a larger area are more conveniently represented as a single area-type emission source. Such emission sources are mainly located within administrative boundaries of cities or industrial zones. This form of emission sources and the use of the vector digital maps enabled us to depart from the necessity of using regular grids, as in traditional GHG inventory approaches. This, in turn, allowed us to significantly increase the resolution of spatial inventories. The grid is only used to present the total emissions from very diverse emission sources in many categories.

The data needed for the calculation of emissions at the source level can be found using statistical data from the lowest available level (province or sub-region) and certain proxy data that reflect the specifics of the analysed processes. In this approach, it is possible to flexibly use even 
the minor data on the specifics of the technological process at each emission source (e.g. the characteristics of the specific fuel used, the specifics of the technological process and so on), which can be reflected in the final emission coefficients values. Assessment of the absolute uncertainties may help in better understanding which industrial processes mainly contribute to the total emission uncertainty, and which subsectors or emission categories should be first approached to decrease the relative uncertainty of the emission factors and activity data.

\subsection{Main emission sources}

Emissions from electricity generation $\left(145,987.4 \mathrm{Gg} \mathrm{CO}_{2}\right.$-eq. from all point-type emission sources in this category in Poland in 2010) form the main share of industrial emissions. Most of these emission sources are located in the Silesian (SLK, 32,169.3 $\mathrm{Gg} \mathrm{CO}_{2}$-eq.), Łódź (LDZ, 24,944.2 $\mathrm{Gg} \mathrm{CO}_{2}$-eq.) and Greater Poland (WKP, 22,590.0 Gg CO $\mathrm{CO}_{2}$-eq.) Provinces. The coalfuelled power plants are sources of huge emissions, namely, Bełchatów in Łódź Province which is the largest power plant in Europe using coal $\left(21,926 \mathrm{Gg} \mathrm{CO}_{2}\right.$-eq.), the Patnów II power plant in the Greater Poland Province (17,896 Gg CO 2 -eq.) and the Rybnik power plant in the Silesian Province (11,630 $\mathrm{Gg} \mathrm{CO}_{2}$-eq.). Public heat production causes much smaller emissions (13,968.0 $\mathrm{Gg} \mathrm{CO}_{2}$-eq. in total). The highest emissions are in large cities, like Warszawa (1363.8 $\mathrm{Gg} \mathrm{CO}_{2}$-eq.), Wrocław (618.7 $\mathrm{Gg} \mathrm{CO}_{2}$-eq.) and Katowice (475.2 $\mathrm{Gg}$ $\mathrm{CO}_{2}$-eq.). The carbon dioxide emissions from the fossil fuel combustion in electricity generation and heat production prevail and constitute $99.53 \%$ of all industrial emissions under investigation.

The fossil fuels are also combusted in the petroleum refining and manufacture of the solid fuels (8939.5 $\mathrm{Gg} \mathrm{CO}_{2}$-eq. in total). The point-type emission sources of these types, like refineries and coke plants, are located only in a few provinces: Masovian (MAZ, 3734.5 Gg $\mathrm{CO}_{2}$-eq.), Silesian (SLK, $3273.7 \mathrm{Gg} \mathrm{CO}_{2}$-eq.) and Pomeranian (POM, $1251.0 \mathrm{Gg} \mathrm{CO}_{2}$-eq.).

The manufacturing industry and construction subsector $\left(30,964.3 \mathrm{Gg} \mathrm{CO}_{2}\right.$-eq. in total) includes processes of the fossil fuel consumption in the metal production (iron and steel production, non-ferrous metals and so on) mainly in industrial areas (5897.1 $\mathrm{Gg} \mathrm{CO}_{2}$-eq.); in the chemical industry, both in the cities and industrial areas (8152.1 $\mathrm{Gg} \mathrm{CO}_{2}$-eq.); in the food processing (4157.3 $\mathrm{Gg} \mathrm{CO}_{2}$-eq.); and in others (12,765.7 $\mathrm{Gg} \mathrm{CO}_{2}$-eq.). The highest emissions in this subsector are in industrialised Silesian (SLK, $7456.3 \mathrm{Gg} \mathrm{CO}_{2}$-eq.) and Masovian (MAZ, 6493.5 Gg CO $\mathrm{CO}_{2}$-eq.) Provinces, and the smallest is in the Podlaskie (PDL, $345.4 \mathrm{Gg} \mathrm{CO}_{2}$-eq.) Province.

The fugitive emissions consist mainly of methane $(555.76 \mathrm{Gg}$ in total) and carbon dioxide $(1812.24 \mathrm{Gg})$. They come from the point-type emission sources of coal mining and handling (339.68 $\mathrm{Gg} \mathrm{CH}_{4}$ ), coke oven gas subsystems (1623.19 $\mathrm{Gg} \mathrm{CO}_{2}$ and $4.36 \mathrm{Gg} \mathrm{CH}_{4}$ ), oil production (185.07 $\mathrm{Gg} \mathrm{CO}_{2}$ and $1.96 \mathrm{Gg} \mathrm{CH}_{4}$ ), oil refining/storage $\left(710.2 \mathrm{Mg} \mathrm{CH}_{4}\right.$ ) and natural gas production (209.05 $\mathrm{Gg} \mathrm{CH}_{4}$ and $3.99 \mathrm{Gg} \mathrm{CO}_{2}$ ). The highest fugitive emissions are in the Silesian Province (SLK, $9397.3 \mathrm{Gg} \mathrm{CO}_{2}$-eq., coal mining and handling, coke oven gas subsystems), the Subcarpathian Province (PKR, 3175.0 Gg $\mathrm{CO}_{2}$-eq., oil and natural gas production) and the Lesser Poland Province (MLP, $1382.3 \mathrm{Gg} \mathrm{CO}_{2}$-eq., oil and natural gas production, coke oven gas subsystems).

The chemical industry is growing in Poland, and it represents all major categories. The inorganic chemical industry is based on rich deposits of rock salt and sulphur. The rock salt is mined near Inowroław and Kłodawa, while sulphur is mined in the Świętokrzyskie and Subcarpathian Voivodeships. The production centres of nitrogen fertilisers are Puławy, 
Table 1 Main emission sources in categories 2A-2G according to IPCC classification: mineral products, chemical industry, metal production and others (Poland 2010)

\begin{tabular}{|c|c|c|}
\hline IPCC category (total emissions) & Main emission sources (province) & Emissions \\
\hline \multicolumn{3}{|l|}{ Mineral products } \\
\hline \multirow{3}{*}{$\begin{array}{l}\text { 2.A.1 Cement production } \\
\quad\left(6254.56 \mathrm{Gg} \mathrm{CO}_{2}\right)\end{array}$} & Cementownia Górażdże (OPL) & $1253.38 \mathrm{Gg} \mathrm{CO}_{2}$ \\
\hline & Cementownia Warta (LDZ) & $712.25 \mathrm{Gg} \mathrm{CO}_{2}$ \\
\hline & Cementownia Małogoszcz (SWK) & $644.44 \mathrm{Gg} \mathrm{CO} 2$ \\
\hline $\begin{array}{l}\text { 2.A.2 Lime production } \\
\qquad\left(1379.76 \mathrm{Gg} \mathrm{CO}_{2}\right)\end{array}$ & KW Czatkowice Sp. z o.o. (MLP) & $197.11 \mathrm{Gg} \mathrm{CO}_{2}$ \\
\hline \multirow{3}{*}{$\begin{array}{l}\text { 2.A.3 Limestone and dolomite } \\
\text { use }\left(1526.87 \mathrm{Gg} \mathrm{CO}_{2}\right)\end{array}$} & Elektrownia Rybnik SA (SLK) & $165.39 \mathrm{Gg} \mathrm{CO} 2$ \\
\hline & Elektrownia Bełchatów (LDZ) & $155.84 \mathrm{Gg} \mathrm{CO}_{2}$ \\
\hline & Elektrownia Pątnów (WKP) & $127.20 \mathrm{Gg} \mathrm{CO}_{2}$ \\
\hline $\begin{array}{l}\text { 2.A.4 Soda ash production and use } \\
\left(261.15 \mathrm{Gg} \mathrm{CO}_{2}\right)\end{array}$ & Soda Mątwy SA (KPM) & $130.57 \mathrm{Gg} \mathrm{CO}_{2}$ \\
\hline \multirow{3}{*}{$\begin{array}{l}\text { 2.A.7 Glass production } \\
\qquad\left(360.98 \mathrm{Gg} \mathrm{CO}_{2}\right)\end{array}$} & Pilkington Polska Sp. z o.o.(SWK) & $48.57 \mathrm{Gg} \mathrm{CO}_{2}$ \\
\hline & Euroglas Polska Sp. z.o.o (LBL) & $45.71 \mathrm{Gg} \mathrm{CO}_{2}$ \\
\hline & Saint-Gobain Glass Polska Sp. Z o.o. (SLK) & $42.86 \mathrm{Gg} \mathrm{CO}$ \\
\hline \multicolumn{3}{|l|}{ Chemical industry } \\
\hline \multirow{3}{*}{$\begin{array}{l}\text { 2.B.1 Ammonia production } \\
\quad\left(3879.2 \mathrm{Gg} \mathrm{CO}_{2} ; 10.09 \mathrm{Gg} \mathrm{CH}_{4}\right)\end{array}$} & Zakłady Azotowe Puławy S.A. (LBL) & $1902.6 \mathrm{Gg} \mathrm{CO}_{2}$-eq. \\
\hline & Anwil S.A. (KPM) & $1011.4 \mathrm{Gg} \mathrm{CO}_{2}$-eq. \\
\hline & Zakłady Chemiczne Police S.A. (ZPM) & $486.3 \mathrm{Gg} \mathrm{CO}_{2}$-eq. \\
\hline \multirow{3}{*}{$\begin{array}{l}\text { 2.B.2 Nitric acid production } \\
\qquad\left(2976.97 \mathrm{Mg} \mathrm{N}_{2} \mathrm{O}\right)\end{array}$} & Zakłady Azotowe Puławy S.A. (LBL) & $1333.85 \mathrm{Mg} \mathrm{N}_{2} \mathrm{O}$ \\
\hline & Anwil S.A. (KPM) & $927.35 \mathrm{Mg} \mathrm{N}_{2} \mathrm{O}$ \\
\hline & Zakłady Azotowe w Tarnowie-Mościcach S.A. (MLP) & $519.41 \mathrm{Mg} \mathrm{N}_{2} \mathrm{O}$ \\
\hline $\begin{array}{l}\text { 2.B.4 Carbide production } \\
\quad\left(2518.50 \mathrm{Mg} \mathrm{CO}_{2}\right)\end{array}$ & Huta Laziska S.A. & $2518.50 \mathrm{Mg} \mathrm{CO} 2$ \\
\hline \multirow{2}{*}{$\begin{array}{l}\text { 2.B.5a Caprolactam production } \\
\left(755.15 \mathrm{Mg} \mathrm{N}_{2} \mathrm{O}\right)\end{array}$} & Zakłady Azotowe w Tarnowie-Mościcach S.A. (MLP) & $416.29 \mathrm{Mg} \mathrm{N}_{2} \mathrm{O}$ \\
\hline & Zakłady Azotowe Puławy S.A. (LBL) & $338.84 \mathrm{Mg} \mathrm{N}_{2} \mathrm{O}$ \\
\hline $\begin{array}{l}\text { 2.B.5b Carbon black production } \\
\left(358.16 \mathrm{Mg} \mathrm{CH}_{4}\right)\end{array}$ & Carbon Black Polska Sp. z o.o. (PKR) & $358.16 \mathrm{Mg} \mathrm{CH}_{4}$ \\
\hline \multirow{2}{*}{$\begin{array}{l}\text { 2.B.5c Ethylene production } \\
\left.\text { (12.70 } \mathrm{Gg} \mathrm{CO}_{2} \text {-eq. }\right)\end{array}$} & Polski Koncern Naftowy Orlen S.A. (MAZ) & $501.80 \mathrm{Mg} \mathrm{CH}_{4}$ \\
\hline & & $150.54 \mathrm{Mg} \mathrm{CO}_{2}$ \\
\hline $\begin{array}{l}\text { 2.B.5e Styrene production } \\
\left(489.08 \mathrm{Mg} \mathrm{CH}_{4}\right)\end{array}$ & Synthos Dwory Sp. z o.o. (MLP) & $489.08 \mathrm{Mg} \mathrm{CH}_{4}$ \\
\hline \multicolumn{3}{|l|}{ Metal production } \\
\hline \multirow{2}{*}{$\begin{array}{l}\text { 2.C.1a Iron ore sinter production } \\
\left.\text { (1454.93 } \mathrm{Gg} \mathrm{CO}_{2} \text {-eq. }\right)\end{array}$} & Arcelor Mittal Poland S.A. (D.G., SLK) & $1149.21 \mathrm{Gg} \mathrm{CO}_{2}$ \\
\hline & Arcelor Mittal Poland S.A. (Krakow, MLP) & $295.51 \mathrm{Gg} \mathrm{CO}_{2}$ \\
\hline \multirow{2}{*}{$\begin{array}{l}\text { 2.C.1c Steel cast production } \\
\left(6846.27 \mathrm{Mg} \mathrm{CO}_{2}\right)\end{array}$} & CMC Zawiercie S.A. (SLK) & $2697.83 \mathrm{Mg} \mathrm{CO}_{2}$ \\
\hline & CELSA 'Huta Ostrowiec' Sp. z o.o. (SWK) & $1,660.21 \mathrm{Mg} \mathrm{CO} 2$ \\
\hline \multirow{3}{*}{$\begin{array}{l}\text { 2.C.1d Iron cast production } \\
\text { (22.47 } \mathrm{Gg} \mathrm{CO}_{2} \text {-eq.) }\end{array}$} & Odlewnie Polskie S.A. (SLK) & $11.23 \mathrm{Gg} \mathrm{CO}_{2}$-eq. \\
\hline & Odlewnia Żeliwa ‘Śrem’ S.A. (MLP) & $7.49 \mathrm{Gg} \mathrm{CO}_{2}$-eq. \\
\hline & Stalmag Ltd. (SLK) & $3.75 \mathrm{Gg} \mathrm{CO}_{2}$-eq. \\
\hline \multirow{4}{*}{$\begin{array}{l}\text { 2.C.1e Pig iron production in } \\
\text { blast furnaces ( } 2857.52 \mathrm{Gg} \mathrm{CO}_{2} \text {-eq.) } \\
\text { 2.C.1f Basic oxygen furnace } \\
\text { steel production ( } 451.97 \mathrm{Gg} \mathrm{CO}_{2} \text {-eq.) }\end{array}$} & Arcelor Mittal Poland S.A. (D.G., SLK) & $1964.6 \mathrm{Gg} \mathrm{CO}_{2}$-eq. \\
\hline & Arcelor Mittal Poland S.A. (Krakow, MLP) & $892.98 \mathrm{Gg} \mathrm{CO}_{2}$-eq. \\
\hline & Arcelor Mittal Poland S.A. (D.G., SLK) & $297.35 \mathrm{Gg} \mathrm{CO}_{2}$-eq. \\
\hline & Arcelor Mittal Poland S.A. (Krakow, MLP) & $154.62 \mathrm{Gg} \mathrm{CO}_{2}$-eq. \\
\hline \multirow{2}{*}{$\begin{array}{l}\text { 2.C.1g Electric furnace steel } \\
\text { production }\left(350.73 \mathrm{Gg} \mathrm{CO}_{2} \text {-eq.) }\right.\end{array}$} & CMC Zawiercie S.A. (SLK) & $102.06 \mathrm{Gg} \mathrm{CO}_{2}$-eq. \\
\hline & CELSA 'Huta Ostrowiec' Sp. z o.o. (SWK) & $62.80 \mathrm{Gg} \mathrm{CO}_{2}$-eq. \\
\hline $\begin{array}{l}\text { 2.C.2 Ferroalloys production } \\
\left(208.84 \mathrm{Gg} \mathrm{CO}_{2} \text {-eq. }\right)\end{array}$ & Huta Laziska S.A. (SLK) & $\begin{array}{l}207.52 \mathrm{Gg} \mathrm{CO}_{2} \\
53.21 \mathrm{Mg} \mathrm{CH}_{4}\end{array}$ \\
\hline 2.C. 3 Aluminium production & Huta Aluminium Konin (WKP) & $\begin{array}{l}28.72 \mathrm{Gg} \mathrm{CO}_{2} \\
5.95 \mathrm{Mg} \mathrm{CF}_{4} \\
0.431 \mathrm{Mg} \mathrm{C}_{2} \mathrm{~F}_{6}\end{array}$ \\
\hline \multirow{2}{*}{$\begin{array}{l}\text { 2.C.5 Zinc and lead production } \\
\left(215.87 \mathrm{Gg} \mathrm{CO}_{2}\right)\end{array}$} & Huta Cynku 'Miasteczko Śląskie' (SLK) & $91.09 \mathrm{Gg} \mathrm{CO}_{2}$ \\
\hline & ZM Silesia S.A. Zakład Katowice (SLK) & $62.39 \mathrm{Gg} \mathrm{CO} 2$ \\
\hline \multicolumn{3}{|l|}{ Other technological processes } \\
\hline $\begin{array}{l}\text { 2.D.1a Paper production } \\
\qquad\left(8.72 \mathrm{Gg} \mathrm{CO}_{2} ; 30.52 \mathrm{Gg} \mathrm{SO}_{2} ; 24.42\right.\end{array}$ & International Paper-Kwidzyn Sp. z o.o. (POM) & $\begin{array}{l}532.7 \mathrm{Mg} \mathrm{CO}_{2} \\
1.86 \mathrm{Gg} \mathrm{SO}_{2} \\
1.49 \mathrm{Gg} \mathrm{CO}\end{array}$ \\
\hline
\end{tabular}


Table 1 (continued)

\begin{tabular}{|c|c|c|}
\hline IPCC category (total emissions) & Main emission sources (province) & Emissions \\
\hline \multirow{2}{*}{\multicolumn{2}{|c|}{$\begin{array}{l}\text { Gg CO; } 16.13 \text { Gg NMVOC; } 6.54 \text { Gg } \\
\text { NO })\end{array}$}} & 985.4 Mg NMVOC \\
\hline & & $399.5 \mathrm{Mg} \mathrm{NO}$ \\
\hline \multirow{4}{*}{\multicolumn{2}{|c|}{$\begin{array}{l}\text { 2.D.1b Pulp production } \\
\qquad\left(1.76 \mathrm{Gg} \mathrm{SO}_{2} ; 4.85 \mathrm{Gg} \mathrm{CO} ;\right. \\
\left.1.77 \mathrm{Gg} \mathrm{NMVOC} ; 881.0 \mathrm{Mg} \mathrm{NO}_{\mathrm{X}}\right)\end{array}$}} & $781.0 \mathrm{Mg} \mathrm{SO}$ \\
\hline & & $2.15 \mathrm{Gg} \mathrm{CO}$ \\
\hline & & $784.4 \mathrm{Mg}$ NMVOC \\
\hline & & $390.5 \mathrm{Mg} \mathrm{NO}_{\mathrm{X}}$ \\
\hline $\begin{array}{l}\text { 2.D.2f Sugar production } \\
\text { (15.79 Gg NMVOC) }\end{array}$ & Pfeifer \& Langen Glinojeck S.A. (MAZ) & 1.72 Gg NMVOC \\
\hline
\end{tabular}

Włocławek, Kędzierzyn-Koźle and Tarnów. The largest production centres of phosphate fertilisers are Police, Gdańsk and Tarnobrzeg. The middle part of the country (Warszawa, Łódź, Bydgoszcz and Inowrocław) offers various products of organic and inorganic chemistry.

In the mineral product subsector, the highest emissions come from cement production processes (Table 1), with smaller contributions from lime production and limestone and dolomite use. In the chemical industry, the highest emissions are from ammonia (4131.45 $\mathrm{Gg} \mathrm{CO}_{2}$-eq.), nitric acid (887.14 $\mathrm{Gg} \mathrm{CO}_{2}$-eq.) and caprolactam (225.03 $\mathrm{Gg} \mathrm{CO}_{2}$-eq.) production. In metal production, the highest GHG emissions are from pig iron production in blast furnaces $(2857.52$ $\mathrm{Gg} \mathrm{CO}_{2}$-eq.) and iron ore sinter production (1454.93 $\mathrm{Gg} \mathrm{CO}_{2}$-eq.). The main emission sources are the metalworks of Arcelor Mittal Poland S.A. in Dąbrowa Górnicza and Kraków.

The GHG total emissions in Poland in 2010 from the mineral products, chemical industry, metal production and others (i.e. all categories $2 \mathrm{~A}-2 \mathrm{G}$ according to IPCC classification, see Fig. 1), are 20,670.0 $\mathrm{Gg} \mathrm{CO}_{2}$-eq. (19,217.5 $\mathrm{Gg} \mathrm{CO}_{2}, 13.07 \mathrm{Gg} \mathrm{CH}_{4}$ and $\left.3.78 \mathrm{Gg} \mathrm{N}_{2} \mathrm{O}\right)$. The highest emissions are in the Silesian (SLK, $4859.8 \mathrm{Gg} \mathrm{CO}_{2}$-eq.), Lublin (LBL, $3649.3 \mathrm{Gg} \mathrm{CO}_{2}$-eq.), Lesser Poland (MAL, $2437.9 \mathrm{Gg} \mathrm{CO}$-eq.) and Holy Cross (SWK, $2430.3 \mathrm{Gg} \mathrm{CO}_{2}$-eq.) Provinces, and the smallest is in the Podlaskie (PDL, $102.3 \mathrm{Gg} \mathrm{CO}_{2}$-eq.) and Subcarpathian (PKR, 115.0 Gg $\mathrm{CO}_{2}$-eq.) Provinces.

\subsection{Comparison with EDGAR inventory data}

The results of our spatial GHG emissions from the industrial processes at the emission source level (labelled in the sequel as the GESAPU results, which is the acronym of the European Union FP7 Marie Curie Actions IRSES project no. 247645) are compared with the EDGAR (2013) global gridded emission data. For this comparison, the GESAPU results at the level of the point- and area-type emission sources were first aggregated to a $0.5^{\prime} \times 0.5^{\prime}$ latitude and longitude grid, the same as the ODIAC grid (Oda and Maksyutov 2015) and, then, were aggregated again to the EDGAR grid with a resolution of $0.1^{\circ} \times 0.1^{\circ}$ latitude and longitude. As we can see in Fig. 10, each EDGAR cell contains exactly $12 \times 12=144$ GESAPU/ODIAC cells.

Comparisons for subsectors (Fig. 11) show generally good correlation of the results. The highest uncertainties of the gridded emissions are connected with poor localisation of the point-type emission sources (see also discussion of this problem in Hogue et al. 2016; Woodard et al. 2015; Zheng et al. 2017), which depends on the grid size (Hogue et al. 
2019). The GESAPU results are obtained from the spatial inventory at the emission source level, where the point-type emission sources (here the stacks of the power plants) were inspected individually, that highly improved accuracy of the localisation to a few dozen meters (because of multiple stacks in most of the power plants that were modelled as one stack with geographical coordinates calculated as the geometric mean of all stack coordinates). The EDGAR estimates are based on the CARMA (2017) database, which has much higher localisation errors. In the upper part of Fig. 11, an example is presented that demonstrates two neighbouring EDGAR cells in the Łódź Province that suggest a high difference in the results. These cells are connected with the largest Polish power plant Bełchatów. In the EDGAR results, the emissions from this power plant are placed in the red cell. However, as presented in the enlarged panel on the left, this cell contains the town Bełchatów, while the power plant is actually localised a few kilometres to the south and should be placed in another cell (the blue one). There are much more erroneous localisations of the point-type emission sources in Katowice agglomeration in the figure. The bottom panel (b) of Fig. 11 contains similar misplacements for the manufacturing industry subsector. In the EDGAR database, the point-type emission sources of the coke plants and the metal production are localised in the red cells, while actually they should be placed a few kilometres to the north, in the blue cells.

\subsection{Main sources of uncertainty}

Analysis of the uncertainties presented in Fig. 9 shows that the highest absolute uncertainties of the GHG inventories are in the Silesian Province (SLK, $1549.8 \mathrm{Gg} \mathrm{CO}_{2}$-eq.), which is obviously caused by the huge industrial potential of this province. The uncertainty of the emission from the electricity generation is the highest (1088.5 $\mathrm{Gg} \mathrm{CO}_{2}$-eq.) due to huge emissions of carbon dioxide, even if their relative uncertainty is small, and the uncertainties of the fugitive emissions (1041.3 $\mathrm{Gg} \mathrm{CO}_{2}$-eq.), which is mainly due to the

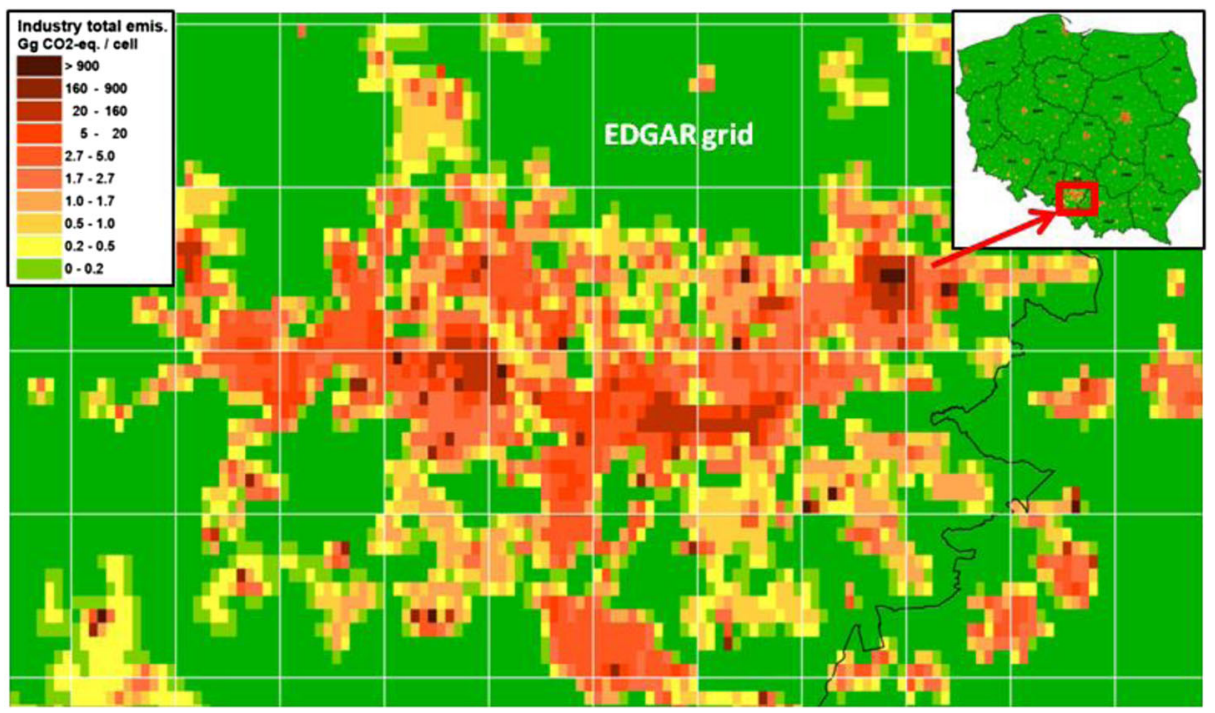

Fig. 10 Illustration of GESAPU results at ODIAC grid (colour cells) and the EDGAR grid (white): an enlarged part of the GESAPU total emissions from the industrial processes for the industrial part of the Silesian Province (given also as the $3 \mathrm{D}$ prism map in the bottom panel of Fig. 6), $\mathrm{Gg} \mathrm{CO}_{2}$-eq. per cell, 2010 
methane emissions from the coal mining and handling and partly by the fugitive emissions from the coke oven gas subsystems. Almost half of them are the absolute uncertainties for the Łódź (LDZ, 848.3 Gg $\mathrm{CO}_{2}$-eq.) and Greater Poland Provinces (WKP, $767.3 \mathrm{Gg} \mathrm{CO}$-eq.), mainly due to the uncertainties of the emissions from electricity generation (844.4 and $764.8 \mathrm{Gg} \mathrm{CO}_{2}$-eq., respectively). The smallest absolute uncertainties are for the Podlaskie, Warmian-Masurian and Lubusz Provinces (PDL, 26.9; WMZ, 30.8; and LBU, 35.3 Gg $\mathrm{CO}_{2}$-eq., respectively). These are mostly caused by the uncertainties of the emission processes from electricity generation, public heat production and the chemical transformation of materials.

In almost all provinces, the absolute uncertainties from the electricity generation dominate. Only in some provinces are the uncertainties from the fugitive emissions comparable, especially in the Silesian (SLK, $1041.3 \mathrm{Gg} \mathrm{CO}_{2}$-eq., mainly due to emissions from
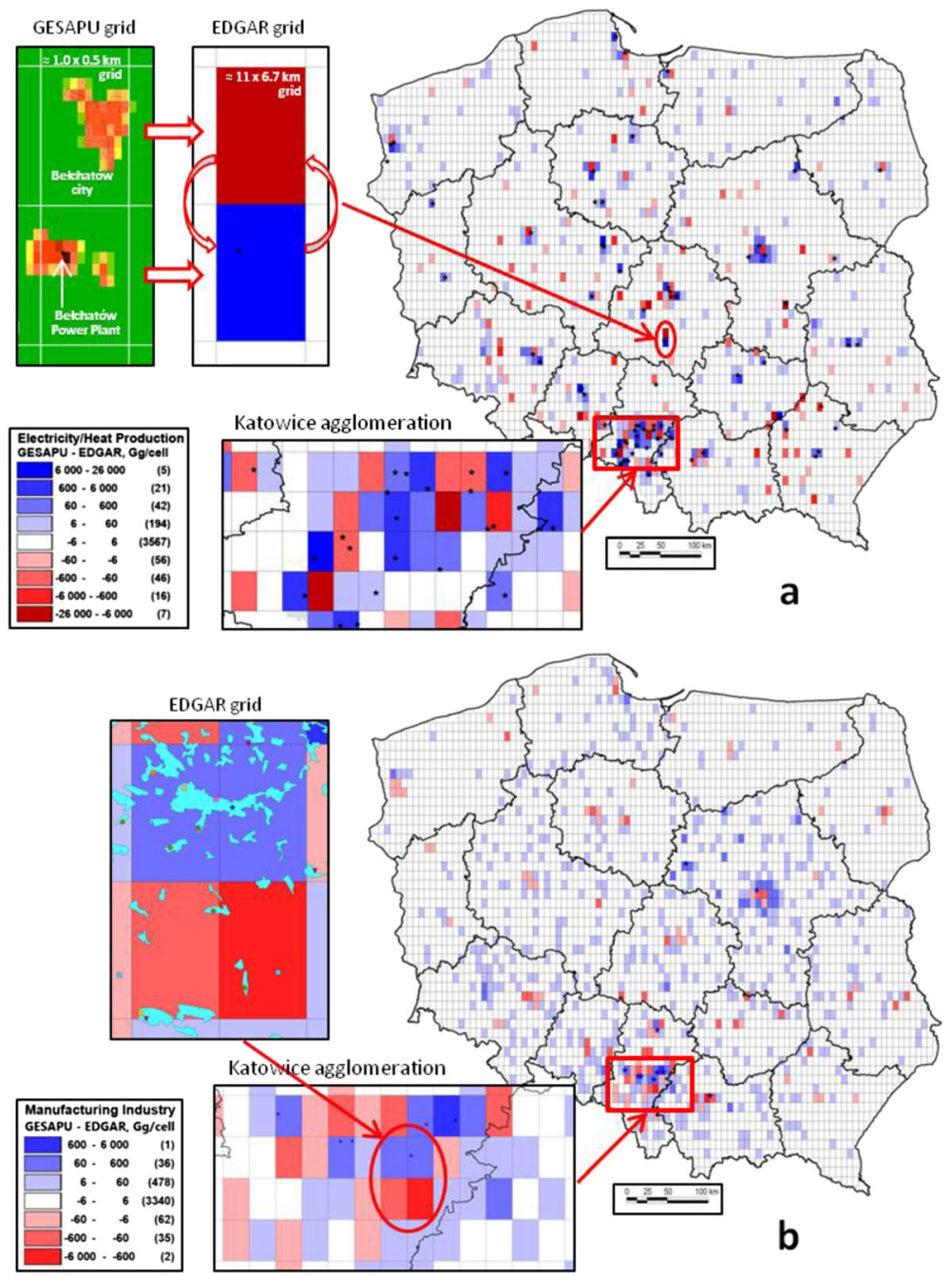

Fig. 11 Comparison of GESAPU and EDGAR results for $\mathrm{CO}_{2}$ emissions from power and heat production (a) and the manufacturing industry (b) 
coal mining and handling), Subcarpathian (PKR, $409.3 \mathrm{Gg} \mathrm{CO}_{2}$-eq., mainly due to emissions from natural gas production) and Lesser Poland Provinces (MLP, 165.0 Gg $\mathrm{CO}_{2}$-eq., mainly due to emissions from oil and natural gas production, as well as by coke oven gas subsystems).

The absolute uncertainties of GHG emissions from public heat production are related with the use of fossil fuels and are high for the provinces with large urbanised areas, especially in the Silesian (SLK, 79.8 Gg CO 2 -eq.), Masovian (MAZ, $60.6 \mathrm{Gg} \mathrm{CO}_{2}$-eq.) and Lower Silesian (DLS, $36.0 \mathrm{Gg} \mathrm{CO}$-eq.) Provinces. The absolute uncertainties of $\mathrm{GHG}$ emissions from the fuel processing are also due to the fossil fuel use (mainly the solid fuels) for petroleum refining and manufacturing of solid fuels in coke plants: Masovian Province (MAZ, $126.7 \mathrm{Gg} \mathrm{CO}_{2}$-eq.), Silesian Province (SLK, 111.2 $\mathrm{Gg} \mathrm{CO}_{2}$-eq.) and Pomeranian Province (POM, $42.4 \mathrm{Gg} \mathrm{CO}_{2}$-eq.).

The absolute uncertainties of GHG emissions from the manufacturing industry are the highest for the provinces, where fossil fuels (mainly solid fuels) are used for metal production: Silesian Province (SLK, 208.9 Gg CO 2 -eq.), Masovian Province (MAZ, 183.9 Gg CO $\mathrm{CO}_{2}$-eq.) and Lesser Poland Province (MLP, $88.0 \mathrm{Gg} \mathrm{CO}_{2}$-eq.). The absolute uncertainties of the GHG total emissions that include methane, carbon dioxide, nitrous oxide and other GHGs from the industrial processes, like mineral products, the chemical industry, metal production and so on, are in the Silesian (SLK, 265.2 $\mathrm{Gg} \mathrm{CO}_{2}$-eq.), Lublin (LBL, 223.7 $\mathrm{Gg} \mathrm{CO}_{2}$-eq.) and Lesser Poland Provinces (MLP, $143.5 \mathrm{Gg} \mathrm{CO}_{2}$-eq.).

\section{Conclusions}

The main purpose of this study was to present a novel approach to high-definition spatial inventory of GHGs from various technological processes in industry and to analyse the spatial heterogeneity of these processes when using this approach. This is caused by many factors, but primarily is due to heterogeneity of the raw material and human resource locations.

It is demonstrated in the study that we are able to practically eliminate the uncertainty due to point source spatial misallocations, which are present in commonly used global emission databases, like EDGAR. Vector digital maps help us to consider the boundaries of administrative units even at the lowest level (like municipalities) and aggregate accurately the results within these units. At the same time, our high-definition spatially explicit model has unique flexibility characteristics, as it is simple to change or form anew the emission field when any changes in emission processes are known or detected, by using our geoinformation technology. This gives a much better possibility to follow any partial local alterations of emissions, due, e.g. to stopping some activities in the considered area.

Our method is general and can be applied in any other case. However, it requires a rather laborious preparation of the geoinformation tools and assembling of possibly the most detailed data on emission sources.

The high-definition GHG spatial inventories from industrial processes for separate emission categories, separate GHGs, or separate administrative units of different levels give an opportunity to assess their potential for reducing anthropogenic impact on the atmospheric carbon content and serve as a tool to support well-grounded decision-making. They are also important for more accurate modelling of the GHG atmospheric dispersions with high resolution. This kind of modelling is important whenever the concentration of GHGs in the local atmosphere are measured and the measurements are considered to be used for confronting bottom-up and 
top-down approaches, e.g. to compare/verify the results from modelling and measurements, to use inverse methods and so on.

Our study offers ways to accurately model regional GHG emissions, which is often difficult for global emission modelling framework due to the trade-off between the lack of regional details vs. global consistency, and reduce the uncertainties of global emissions. In that regard, we also consider the comparison to EDGAR has partially shown how we could transfer the knowledge from regional studies to global modelling, because, as stated earlier, the lack of regional specificity is one of the major sources of uncertainties in global emissions modelling. We also would like to note that although our modelling approach covers the entire domain of Poland (national), it demonstrates a way to accurately quantify industrial emissions at a policy relevant spatial scale in order to contribute to the local climate mitigation via emission quantification (local to national) and scientific assessment of the mitigation effort (national to global).

Acknowledgments The study was conducted within the European Union FP7 Marie Curie Actions IRSES project no. 247645, acronym GESAPU.

\section{Appendix}

\section{Formulas for disaggregation of activity data and emission calculation}

Metallurgy The disaggregation coefficient $D_{\text {metal, } f, i}$ for the $f$ th type of fossil fuel in the $i$ th metallurgy plant $\eta_{\text {metal }, i}$ depends on available data on the production of various types of metals, and it can be calculated using the following formulas:

1) for the industrial zone where is located one of the 10 largest steel mills that produce $80 \%$ of all steel products in Poland:

$$
D_{\text {metal }, f, i}\left(\eta_{\text {metal }, i}\right)=k_{\text {metal }} \times \frac{V_{\text {metal }}\left(\eta_{i}\right)}{\sum_{j} V_{\text {metal }}\left(\eta_{j}\right)},
$$

where $V_{\text {metal }}\left(\eta_{i}\right)$ is the production capacity of the $i$ th steel mill; $k_{\text {metal }}$ is the known share of the metal production for the 10 largest steel mills;

2) for the smaller industrial objects with unknown production capacities, we use the formula:

$$
D_{\text {metal }, f, i}\left(\eta_{\text {metal }, i}\right)=\left(1-k_{\text {metal }}\right) \times \frac{G V A_{r}}{\sum_{r_{w}=1}^{R_{w}} G V A_{r_{w}}} \times \frac{S_{i}}{\sum_{j=1}^{J_{r_{w}} S_{j}}},
$$

where $G V A_{r_{w}}$ is the gross value added in the metallurgy sector of the $r_{w}$ th sub-region in Poland, $S_{i}$ is the area of the industrial zones where steel mill $\eta_{\text {metal, } i}$ is situated.

Food processing Disaggregation of the activity data from the province level to the sub-region level was carried out by using the gross value added as proxy data. Finally, disaggregation of the activity data to the settlement level was carried out using the data on the number of the 
inhabitants in the settlements. In this case, the disaggregation coefficient $D_{\text {food, } i}$ for the activity data in the food processing industry of the $i$ th settlement is calculated using the formula:

$$
D_{\text {food }, i}=\frac{G V A_{r}}{\sum_{r_{w}} G V A_{r_{w}}} \times \frac{P_{i}}{\sum_{j} P_{j}},
$$

where $G V A_{r}$ is the gross value added in the sub-region where the $i$ th settlement is situated, and $P_{i}$ is the number of the inhabitants in this settlement.

Other categories of manufacturing industry The disaggregation of the activity data on the fossil fuels used from the provincial level to the sub-region level was performed using the gross value added as proxy data. Then, the fuel was disaggregated to the industrial zones in proportion to the areas. Accordingly, the disaggregation coefficient $D_{\mathrm{other}, i}$ for the activity data in the other categories of the manufacturing industry of the $i$ th industrial zone is calculated using the formula:

$$
D_{\text {other }, i}=\frac{G V A_{r}}{\sum_{r_{w}} G V A_{r_{w}}} \cdot \frac{S_{i}}{\sum_{j} S_{j}}
$$

where $G V A_{r}$ is the gross value added in the sub-region where the $i$ th industrial zone is situated, and $S_{i}$ is the area of this zone.

Fuel combustion activity: petroleum refining To assess GHG emissions from the fossil fuels combustion for petroleum refining we used the formula:

$$
E_{\mathrm{ref}, f, g, i}=A_{\mathrm{ref}, f} \times D_{\mathrm{ref}, f, i} \times F_{\mathrm{ref}, f, g, i}, g \in\left\{\mathrm{CO}_{2}, \mathrm{~N}_{2} \mathrm{O}, \mathrm{CH}_{4}\right\},
$$

where $E_{\mathrm{ref}, f, g, i}$ are the annual emissions of the $g$ th GHG from the $f$ th fossil fuel type at the $i$ th refinery, $f \in$ \{liquid, gaseous $\} ; A_{\text {ref, } f}$ are the activity data on the $f$ th fossil fuel type used for the petroleum refining in Poland; $D_{\text {ref, }, f i}$ is the disaggregation coefficient for the $f$ th fossil fuel type for the $i$ th refinery; $F_{\text {ref, } f, g, i}$ is the emission factor of the $g$ th GHG for the $f$ th fossil fuel type used in the $i$ th refinery. This emission factor was calculated using the production capacities of the refineries as proxy data by the formula $D_{\text {ref, } f, i}=P_{\text {ref, } i} / \sum_{j} P_{\text {ref, } j}$, where $P_{\text {coke, } i}$ is the production capacity of the $i$ th refinery.

Fuel combustion activity: manufacturing of solid fuels To assess GHG emissions from the fossil fuels combustion for manufacturing of the solid fuels in the coke ovens we used the formula:

$$
E_{\mathrm{coke}, f, g, i}=A_{\mathrm{coke}, f} \times D_{\text {coke }, f, i} \times F_{\text {coke }, f, g, i}, g \in\left\{\mathrm{CO}_{2}, \mathrm{~N}_{2} \mathrm{O}, \mathrm{CH}_{4}\right\},
$$

where $E_{\text {coke, } f, g, i}$ are the annual emissions of the $g$ th GHG from the $f$ th fossil fuel type at the $i$ th coke ovens, $f \in$ \{solid, liquid, gaseous $\} ; A_{\text {coke, } f}$ are the activity data on the $f$ th fossil fuel type used for manufacture of the solid fuel in Poland; $D_{\text {coke, } f, i}$ is the disaggregation coefficient of the $f$ th fossil fuel type for the $i$ th coke oven; $F_{\text {coke, } f, g, i}$ is the emission factor of the the $g$ th GHG for the $f$ th type of fossil fuel used in the $i$ th coke oven. The disaggregation coefficient was calculated using the production capacities of the coke plants as proxy data by the formula $P_{\text {coke, }}$ ${ }_{i} / \sum_{j} P_{\text {coke, } j}$, where $P_{\text {coke }}$ ref, $i$ is the production capacity of the $i$ th coke plant. 
Cement production We applied the mathematical description of the carbon dioxide emissions from the cement production at the level of a separate plant as a single point source of emission in the GHG spatial inventory. According to it, the carbon dioxide emission is calculated as the product of the quantity of the clinker produced, $\mathrm{CaO}$ content in the clinker, and the cement kiln dust losses, using the formula:

$$
E_{\text {cem }, \mathrm{CO}_{2}, i}=A_{\text {cem }} \times D_{\text {cem }, i} \times F_{\text {cem }, \mathrm{CO}_{2}, i} \times K_{C K D},
$$

where $E_{\mathrm{cem}, \mathrm{CO}_{2}, i}$ is the amount of the annual carbon dioxide emissions from the $i$ th cement plant; $A_{\text {cem }}$ is the activity data on the clinker production at the national scale; $D_{\text {cem }, i}$ is the disaggregation coefficient for the activity data for the $i$ th cement plant; $F_{\text {cem, } \mathrm{CO}_{2}, i}$ is the emission coefficient for production of the clinker for the $i$ th cement plant; $K_{C K D}$ is the correction coefficient for the losses of the cement kiln dust (it was assumed that $K_{C K D}=$ 1.02). The disaggregation coefficient is calculated using the production capacities of the cement plants as proxy data using the formula $D_{\text {cem, } i}=P_{\text {cem, } i} / \sum_{j} P_{\text {cem, } j}$, where $P_{\text {cem }, i}$ is the production capacity of the $i$ th cement plant.

Open Access This article is distributed under the terms of the Creative Commons Attribution 4.0 International License (http://creativecommons.org/licenses/by/4.0/), which permits unrestricted use, distribution, and reproduction in any medium, provided you give appropriate credit to the original author(s) and the source, provide a link to the Creative Commons license, and indicate if changes were made.

Publisher's Note Springer Nature remains neutral with regard to jurisdictional claims in published maps and institutional affiliations.

\section{References}

Akbostanci E, Tunç GI, Türüt-Așik S (2011) CO2 emissions of Turkish manufacturing industry: a decomposition analysis. Appl Energy 88(6):2273-2278. https://doi.org/10.1016/j.apenergy.2010.12.076

Akimoto H, Narita H (1994) Distribution of SO2, NOx and CO2 emissions from fuel combustion and industrial activities in Asia with $1^{\circ} \times 1^{\circ}$ resolution. Atmos Environ 28(2):213-225. https://doi.org/10.1016/1352-2310 (94)90096-5

Andres RJ, Marland G, Fung I, Matthews E (1996) A $1^{\circ} \times 1^{\circ}$ distribution of carbon dioxide emissions from fossil fuel consumption and cement manufacture, 1950-1990. Glob Biogeochem Cycles 10(3):419-429. https://doi.org/10.1029/96GB01523

Andres RJ, Boden TA, Marland G (2009) Annual fossil-fuel $\mathrm{CO}_{2}$ emissions: mass of emissions gridded by one degree latitude by one degree longitude. Carbon Dioxide Information Analysis Center. https://doi. org/10.3334/CDIAC/ffe.ndp058.2009

Andrew RM (2018) Global $\mathrm{CO}_{2}$ emissions from cement production. Earth Syst Sci Data 10:195-217. https://doi. org/10.5194/essd-10-195-2018

BDL (2016) Bank Danych Lokalnych (Local Data Bank), GUS, Warsaw, Poland. Available: http://stat.gov. $\mathrm{pl} / \mathrm{bdl}$. Accessed 30 Jun 2017

Boychuk K, Bun R (2014) Regional spatial inventories (cadastres) of GHG emissions in the energy sector: accounting for uncertainty. Clim Chang 124(3):561-574. https://doi.org/10.1007/s10584-013-1040-9

Bun R, Gusti M, Kujii L, Tokar O, Tsybrivskyy Y, Bun A (2007) Spatial GHG inventory: analysis of uncertainty sources. A case study for Ukraine. Water Air Soil Pollut 7(4-5):483-494. https://doi.org/10.1007/s11267006-9116-4

Bun R, Nahorski Z, Horabik-Pyzel J, Danylo O, See L, Charkovska N, Topylko P, Halushchak M, Lesiv M, Valakh M, Kinakh V (2019) Development of a high resolution spatial inventory of GHG emissions for Poland from stationary and mobile sources. Mitig Adapt Strateg Glob Chang. https://doi.org/10.1007 /s11027-018-9791-2 
Büttner G, Kosztra B, Maucha G, Pataki R (2012) Implementation and achievements of CLC2006. Institute of Geodesy, Cartography and Remote Sensing (FÖMI), 65 p

Cai B, Wang J, He J, Geng Y (2016) Evaluating CO2 emission performance in China's cement industry: an enterprise perspective. Appl Energy 166:191-200. https://doi.org/10.1016/j. apenergy.2015.11.006

Charkovska N, Bun R, Nahorski Z, Horabik J (2012) Mathematical modeling and spatial analysis of emission processes in Polish industry sector: cement, lime and glass production. Econtechmod 1(4):17-22

Charkovska N (2015a) Mathematical modeling and spatial analysis of greenhouse gas emission processes in the industrial and agricultural sectors of Poland. $\mathrm{PhD}$ thesis, Lviv Polytechnic National University, p 224

Charkovska N, Bun R, Nahorski Z, Horabik J (2015b) Modelling GHG emissions in the mineral products industry in Poland: an uncertainty analysis. Mathematical Modeling and Computing 2(1):16-26. https://doi. org/10.23939/mmc2015.01.016

Charkovska N, Halushchak M, Bun R, Jonas M (2015c) Uncertainty analysis of GHG spatial inventory from the industrial activity: A case study for Poland. Proceedings of the 4th International Workshop on Uncertainty in Atmospheric Emissions, Warsaw, SRI PAS, pp 57-63

Cheng Y-P, Wang L, Zhang X-L (2011) Environmental impact of coal mine methane emissions and responding strategies in China. Int J Greenh Gas Con 5(1):157-166. https://doi.org/10.1016/j.ijggc.2010.07.007

Corine (2006) Corine Land Cover data. Available: http://www.eea.europa.eu/. Accessed 28 Jun 2017

EDGAR (2013) Emissions Database for Global Atmospheric Research (Joint Research Centre). Available: http://edgar.jrc.ec.europa.eu/. Accessed 03 Aug 2017

Elgowainy A, Han J, Cai H, Wang M, Forman GS, DiVita VB (2014) Energy efficiency and greenhouse gas emission intensity of petroleum products at U.S. refineries. Environ Sci Technol 48(13):7612-7624. https://doi.org/10.1021/es5010347

Elkin HF (2015) Petroleum refinery emissions. Sources of Air Pollution and Their Control: Air Pollution, Stern AC, ed.: 97-121. ISBN: 978-0-12-666553-6

EPA (2018) Global greenhouse gas emissions data. https://www.epa.gov/ghgemissions/global-greenhouse-gasemissions-data. Accessed 20 April 2018

Garnett T (2011) Where are the best opportunities for reducing greenhouse gas emissions in the food system (including the food chain)? Food Policy 36:S23-S32. https://doi.org/10.1016/j.foodpol.2010.10.010

Geng Y, Wei Y-M, Fischedick M, Chiu A, Chen B, Yan J (2016) Recent trend of industrial emissions in developing countries. Appl Energy 166:187-190. https://doi.org/10.1016/j.apenergy.2016.02.060

Griffina PW, Hammondab GP, Normana JB (2018) Industrial energy use and carbon emissions reduction in the chemicals sector: a UK perspective. Appl Energy 227:587-602. https://doi.org/10.1016/j. apenergy.2017.08.010

Gurney KR, Mendoza DL, Zhou Y, Fischer ML, Miller CC, Geethakumar S, de la Rue du Can S (2009) High resolution fossil fuel combustion $\mathrm{CO}_{2}$ emission fluxes for the United States. Environ Sci Technol 43(14): 5535-5541. https://doi.org/10.1021/es900806c

Gurney K, Razlivanov I, Song Y, Zhou Y, Benes B, Abdul-Massih M (2012) Quantification of fossil fuel $\mathrm{CO}_{2}$ emission on the building/street scale for a large US city. Environ Sci Technol 46(21):12194-12202. https://doi.org/10.1021/es3011282

GUS (2016) Główny Urząd Statystyczny (Central Statistical Office of Poland). Available: http://stat.gov.pl/en/. Accessed 10 Jul 2017

Halushchak M (2017) Mathematical modeling and spatial analysis of processes of greenhouse gas emissions from using fuels in the industrial sector in Ukraine and Poland. PhD thesis, Lviv Polytechnic National University, $184 \mathrm{p}$

Halushchak M, Bun R, Jonas M, Topylko P (2015) Spatial inventory of GHG emissions from fossil fuels extraction and processing: an uncertainty analysis. Proceedings of the 4th International Workshop on Uncertainty in Atmospheric Emissions, Warsaw, SRI PAS, 64-70

Halushchak M, Bun R, Shpak N, Valakh M (2016) Modeling and spatial analysis of greenhouse gas emissions from fuel combustion in the industry sector in Poland. Econtechmod 5(1):19-26

Hao H, Geng Y, Hang W (2016) GHG emissions from primary aluminum production in China: regional disparity and policy implications. Appl Energy 166:264-272. https://doi.org/10.1016/j.apenergy.2015.05.056

Hogue S, Marland E, Andres RJ, Marland G, Woodard D (2016) Uncertainty in gridded $\mathrm{CO}_{2}$ emissions estimates. Earth's Future 4(5):225-239. https://doi.org/10.1002/2015EF000343

Hogue S, Roten D, Marland E, Marland G, Boden T (2019) Gridded estimates of $\mathrm{CO}_{2}$ emissions: uncertainty as a function of scale. Mitig Adapt Strateg Glob Chang. https://doi.org/10.1007/s11027-017-9770-z

Hondo H (2005) Life cycle GHG emission analysis of power generation systems: Japanese case. Energy 30(1112):2042-2056. https://doi.org/10.1016/j.energy.2004.07.020 
Hutchins MG, Colby JD, Marland G, Marland E (2017) A comparison of five high-resolution spatially-explicit fossil fuel carbon dioxide emissions inventories. Mitig Adapt Strateg Glob Chang 22(6):26. https://doi. org/10.1007/s11027-016-9709-9

IEA (2016) Medium-term coal market report 2016. http://www.iea.org/newsroom/news/2016/december/mediumterm-coal-market-report-2016.html. Accessed 20 March 2018

IPCC (2001) Good practice guidance and uncertainty management in national greenhouse gas inventories, Penman Jim, Dina Kruger, Ian Galbally, Taka Hiraishi, Buruhani Nyenzi, Sal Emmanuel, Lenadro Buendia, Robert Hoppaus, Thomas Martinsen, Jeroen Meijer, Kyoko Miwa and Kiyoko Tanabe

IPCC (2006) IPCC Guidelines for National Greenhouse Gas Inventories, Prepared by the National Greenhouse Gas Inventories Programme, Eggleston HS, Buendia L, Miwa K, Ngara T, Tanabe K (eds)

IPCC (2013) Climate change 2013: the physical science basis. Contribution of Working Group I to the Fifth Assessment Report of the Intergovernmental Panel on Climate Change. In: Stocker TF, Qin D, Plattner GK, Tignor M, Allen SK, Boschung J, Nauels A, Xia Y, Bex V, Midgley PM (eds) Cambridge University Press, Cambridge, United Kingdom and New York, NY, USA. http:/www.ipcc.ch/report/ar5/wg2/. Cited 05 Sep 2017

IPCC (2014) Climate change 2014: impacts, adaptation, and vulnerability. Part A: global and sectoral aspects. Contribution of Working Group II to the Fifth Assessment Report of the Intergovernmental Panel on Climate Change. In: Field CB, Barros VR, Dokken DJ, Mach KJ, Mastrandrea MD, Bilir TE, Chatterjee M, Ebi KL, Estrada YO, Genova RC, Girma B, Kissel ES, Levy AN, MacCracken S, Mastrandrea PR, White LL (eds) Cambridge University Press, Cambridge and New York. http://www.ipcc.ch/report/ar5/wg2/. Cited 08 Dec 2017

Jarnicka J, Żebrowski P (2019) Learning in GHG emission inventories in terms of uncertainty improvement over time. Mitig Adapt Strateg Glob Chang (this issue)

Jonas M, Żebrowski P (2019) The crux with reducing emissions in the long-term: the underestimated "now" versus the overestimated "then". Mitig Adapt Strateg Glob Chang. https://doi.org/10.1007/s11027-018-9825-9

Kiemle C, Ehret G, Amediek A, Fix A, Quatrevalet M, Wirth M (2017) Potential of spaceborne lidar measurements of carbon dioxide and methane emissions from strong point sources. Remote Sens 9(1137): 1-16. https://doi.org/10.3390/rs9111137

Lamarque JF, Shindell DT, Josse B, Young P, Cionni I, Eyring V, Bergmann D, Cameron-Smith P, Collins WJ, Doherty RM, Dalsoren SB, Faluvegi G, Folberth G, Ghan S, Horowitz LW, Lee Y, MacKenzie IA, Nagashima T, Naik V, Plummer DA, Righi M, Rumbold S, Schulz M, Skeie R, Stevenson DS, Strode S, Sudo K, Szopa S, Voulgarakis A, Zeng G (2013) The atmospheric chemistry and climate model intercomparison project (ACCMIP): overview and description of models, simulations and climate diagnostics. Geosci Model Dev 6(1):179-206. https://doi.org/10.5194/gmd-6-179-2013

Laurent A, Olsen SI, Hauschild MZ (2010) Carbon footprint as environmental performance indicator for the manufacturing industry. CIRP Ann Manuf Technol 59(1):37-40. https://doi.org/10.1016/j.cirp.2010.03.008

Le Quéré C, Moriarty R, Andrew RM, Canadell JG, Sitch S, Korsbakken JI, Friedlingstein P, Peters GP, Andres RJ, Boden TA, Houghton RA, House JI, Keeling RF, Tans P, Arneth A, Bakker DCE, Barbero L, Bopp L, Chang J, Chevallier F, Chini LP, Ciais P, Fader M, Feely RA, Gkritzalis T, Harris I, Hauck J, Ilyina T, Jain AK, Kato E, Kitidis V, Klein Goldewijk K, Koven C, Landschützer P, Lauvset SK, Lefèvre N, Lenton A, Lima ID, Metzl N, Millero F, Munro DR, Murata A, Nabel JEMS, Nakaoka S, Nojiri Y, O'Brien K, Olsen A, Ono T, Pérez FF, Pfeil B, Pierrot D, Poulter B, Rehder G, Rödenbeck C, Saito S, Schuster U, Schwinger J, Séférian R, Steinhoff T, Stocker BD, Sutton AJ, Takahashi T, Tilbrook B, van der Laan-Luijkx IT, van der Werf GR, van Heuven S, Vandemark D, Viovy N, Wiltshire A, Zaehle S, Zeng N (2015) Global carbon budget 2015. Earth Syst Sci Data 7:349-396. https://doi.org/10.5194/essd-7-349-2015

Lina B, Xubc B (2018) Growth of industrial $\mathrm{CO}_{2}$ emissions in Shanghai city: evidence from a dynamic vector autoregression analysis. Energy 151:167-177. https://doi.org/10.1016/j.energy.2018.03.052

Liu J (2016) National carbon emissions from the industry process: production of glass, soda ash, ammonia, calcium carbide and alumina. Appl Energy 166:239-244. https://doi.org/10.1016/j.apenergy.2015.11.005

Liu Z, Dong H, Geng Y, Lu C, Ren W (2014) Insights into the regional greenhouse gas (GHG) emission of industrial processes: a case study of Shenyang, China. Sustainability 6:3669-3685. https://doi.org/10.3390 /su6063669

Liu Z, Guan D, Wei W, Davis SJ, Ciais P, Bai J, Peng S, Zhang Q, Hubacek K, Marland G, Andres RJ, CrawfordBrown D, Lin J, Zhao H, Hong C, Boden TA, Feng K, Peters GP, Xi F, Liu J, Li Y, Zhao Y, Zeng N, He K (2015) Reduced carbon emission estimates from fossil fuel combustion and cement production in China. Nature 524:335-338. https://doi.org/10.1038/nature14677

Liu Z, Geng Y, Adams M, Dong L, Sun L, Zhao J, Dong H, Wu J, Tian X (2016) Uncovering driving forces on greenhouse gas emissions in China' aluminum industry from the perspective of life cycle analysis. Appl Energy 166:253-263. https://doi.org/10.1016/j.apenergy.2015.11.075 
Liu Y, Gruber N, Brunner D (2017) Spatiotemporal patterns of the fossil-fuel $\mathrm{CO}_{2}$ signal in Central Europe: results from a high-resolution atmospheric transport model. Atmos Chem Phys 16:14145-14169. https://oi. org/10.5194/acp-17-14145-2017

Long R, Shao T, Chen H (2016) Spatial econometric analysis of China's province-level industrial carbon productivity and its influencing factors. Appl Energy 166:210-219. https://doi.org/10.1016/j. apenergy.2015.09.100

Motazedi K, Abella JP, Bergerson JA (2017) Techno-economic evaluation of technologies to mitigate greenhouse gas emissions at North American refineries. Environ Sci Technol 51(3):1918-1928. https://doi.org/10.1021 /acs.est.6b04606

NIR (2012) Poland's National Inventory Report 2012, KOBIZE, Warsaw, 2012, 358 p. Available: http://unfccc. int/national_reports. Accessed 09 Jul 2017

Oda T, Maksyutov S (2011) A very high-resolution $(1 \mathrm{~km} \times 1 \mathrm{~km})$ global fossil fuel $\mathrm{CO}_{2}$ emission inventory derived using a point source database and satellite observations of nighttime lights. Atmos Chem Phys 11: 543-556. https://doi.org/10.5194/acp-11-543-2011

Oda T, Maksyutov Sh (2015) ODIAC fossil fuel $\mathrm{CO}_{2}$ emissions dataset (version name: ODIAC2016). Center for Global Environmental Research, National Institute for Environmental Studies. https://doi.org/10.17595 /20170411.001

Oda T, Maksyutov S, Andres RJ (2018) The open-source data inventory for anthropogenic $\mathrm{CO}_{2}$, version 2016 (ODIAC2016): a global monthly fossil fuel $\mathrm{CO}_{2}$ gridded emissions data product for tracer transport simulations and surface flux inversions. Earth Syst Sci Data 10:87-107. https://doi.org/10.5194/essd-1087-2018

Olivier JGJ, Van Aardenne JA, Dentener F, Pagliari V, Ganzeveld LN, Peters JA (2005) Recent trends in global greenhouse gas emissions: regional trends 1970-2000 and spatial distribution of key sources in 2000. J Integr Environ Sci 2(2-3):81-99. https://doi.org/10.1080/15693430500400345

Ometto JP, Bun R, Jonas M, Nahorski Z (Eds) (2015) Uncertainties in greenhouse gas inventories - expanding our perspective. Springer, 239 p. ISBN 978-3-319-15901-0

Park S, Lee S, Jeong SJ, Song HJ, Park JW (2010) Assessment of $\mathrm{CO}_{2}$ emissions and its reduction potential in the Korean petroleum refining industry using energy-environment models. Energy 35(6):2419-2429. https://doi.org/10.1016/j.energy.2010.02.026

Pengab J, Xieab R, Laiac M (2018) Energy-related $\mathrm{CO}_{2}$ emissions in the China's iron and steel industry: a global supply chain analysis. Resour Conserv Recycl 129:392-401. https://doi.org/10.1016/j. resconrec.2016.09.019

Pétron G, Tans P, Frost G, Chao D, Trainer M (2008) High-resolution emissions of $\mathrm{CO}_{2}$ from power generation in the USA. J Geophys Res 113(G4):1-9. https://doi.org/10.1029/2007JG000602

Peylin P, Houweling S, Krol MC, Karstens U, Rödenbeck C, Geels C, Vermeulen A, Badawy B, Aulagnier C, Pregger T, Dalege F, Pieterse G, Cias P, Heinemann M (2011) Importance of fossil fuel emission uncertainties over Europe for $\mathrm{CO}_{2}$ modeling: model intercomparison. Atmos Chem Phys 11:6607-6622. https://doi.org/10.5194/acp-11-6607-2011

Puliafito SE, Allende D, Pinto S, Castesana P (2015) High resolution inventory of GHG emissions of the road transport sector in Argentina. Atmos Environ 101:303-311. https://doi.org/10.1016/j.atmosenv.2014.11.040

Raupach MR, Rayner PJ, Paget M (2010) Regional variations in spatial structure of nightlights, population density and fossil-fuel $\mathrm{CO}_{2}$ emissions. Energ Policy 38(9):4756-4764. https://doi.org/10.1016/j. enpol.2009.08.021

Rayner PJ, Raupach MR, Paget M, Peylin P, Koffi E (2010) A new global gridded data set of $\mathrm{CO}_{2}$ emissions from fossil fuel combustion: methodology and evaluation. J Geophys Res 115(D19):306. https://doi. org/10.1029/2009JD013439

Rehan R, Nehdi M (2005) Carbon dioxide emissions and climate change: policy implications for the cement industry. Environ Sci Pol 8(2):105-114. https://doi.org/10.1016/j.envsci.2004.12.006

Ren S, Yin H, Chen XH (2014) Using LMDI to analyze the decoupling of carbon dioxide emissions by China's manufacturing industry. Environ Dev 9:61-75. https://doi.org/10.1016/j.envdev.2013.11.003

Schneising O, Burrows JP, Dickerson RR, Buchwitz M, Reuter M, Bovensmann H (2014) Remote sensing of fugitive methane emissions from oil and gas production in north American tight geologic formations. Earth's Future 2(10):548-558. https://doi.org/10.1002/2014EF000265

Shan Y, Liu Z, Guan D (2016) CO2 emissions from China's lime industry. Appl Energy 166:245-252. https://doi.org/10.1016/j.apenergy.2015.04.091

Shao S, Liu J, Geng Y, Miao Z, Yang Y (2016) Uncovering driving factors of carbon emissions from China's mining sector. Appl Energy 166:220-238. https://doi.org/10.1016/j.apenergy.2016.01.047

Shi Y, Zhao T (2016) A decomposition analysis of carbon dioxide emissions in the Chinese nonferrous metal industry. Mitig Adapt Strateg Glob Chang 21:823-838. https://oi.org/10.1007/s11027-014-9624-X 
Singer AM, Branham M, Hutchins MG, Welker J, Woodard DL, Badurek CA, Ruseva T, Marland E, Marland G (2014) The role of $\mathrm{CO}_{2}$ emissions from large point sources in emissions totals, responsibility, and policy. Environ Sci Pol 44:190-200. https://doi.org/10.1016/j.envsci.2014.08.001

Su S, Beath A, Guo H, Mallett C (2005) An assessment of mine methane mitigation and utilisation technologies. Prog Energy Combust Sci 31(2):123-170. https://doi.org/10.1016/j.pecs.2004.11.001

Szklo A, Schaeffer R (2007) Fuel specification, energy consumption and $\mathrm{CO}_{2}$ emission in oil refineries. Energy 32(7):1075-1092. https://doi.org/10.1016/j.energy.2006.08.008

Tian Y, Zhu Q, Geng Y (2013) An analysis of energy-related greenhouse gas emissions in the Chinese iron and steel industry. Energy Policy 56:352-361. https://doi.org/10.1016/j.enpol.2012.12.068

Tong D, Zhang Q, Davis SJ, Liu F, Zheng B, Geng G, Xue T, Li M, Hong C, Lu Z, Streets DG, Guan D, He K (2018) Targeted emission reductions from global super-polluting power plant units. Nature Sustainability Analysis 1:59-68. https://doi.org/10.1038/s41893-017-0003-y

Topylko P, Halushchak M, Bun R, Oda T, Lesiv M, Danylo O (2015) Spatial greenhouse gas (GHG) inventory and uncertainty analysis: a case study of electricity generation in Poland and Ukraine. Proceedings of the 4th International Workshop on Uncertainty in Atmospheric Emissions, Warsaw, SRI PAS, 49-56

UNFCCC (1998) Kyoto Protocol to the United Nations Framework Convention on Climate Change, http://unfecc.int/resource/docs/convkp/kpeng.pdf. Accessed 19 Dec 2017

UNFCCC (2015) Paris Agreement, http://unfccc.int/files/essential_background/convention/ application/pdf/english_paris_agreement.pdf. Accessed 19 Dec 2017

UNFCCC (2017) National Inventory Submissions, http://unfecc.int/national_reports/annex_i_ghg inventories/national_inventories_submissions/items/10116.php. Accessed 30 Dec 2017

Verstraete $\mathbf{J}$ (2017) The spatial disaggregation problem: simulating reasoning using a fuzzy inference system. IEEE Trans Fuzzy Syst 25(3):627-641. https://doi.org/10.1109/TFUZZ.2016.2567452

Warmuzinski K (2008) Harnessing methane emissions from coal mining. Process Saf Environ Prot 86(5):315320. https://doi.org/10.1016/j.psep.2008.04.003

WB (2018) World Bank Open Data, https://data.worldbank.org/indicator. Accessed 13 Mar 2018

White Th, Jonas M, Nahorski Z, Nilsson S (Eds.) (2011) Greenhouse gas inventories: dealing with uncertainty. Springer, 343 p. ISBN 978-94-007-1670-4

Woodard D, Branham M, Buckingham G, Hogue S, Hutchins M, Gosky R, Marland G, Marland E (2015) A spatial uncertainty metric for anthropogenic $\mathrm{CO} 2$ emissions. Greenhouse Gas Measurement and Management 4:139-160. https://doi.org/10.1080/20430779.2014.1000793

Wu J, Zhu Q, Liang L (2016) CO2 emissions and energy intensity reduction allocation over provincial industrial sectors in China. Appl Energy 166:282-291. https://doi.org/10.1016/j.apenergy.2016.01.008

Yang H, Liu J, Jiang K, Meng J, Guan D, Xu Y, Tao S (2018) Multi-objective analysis of the co-mitigation of CO2 and PM2.5 pollution by China's iron and steel industry. J Clean Prod 185:331-341. https://oi. org/10.1016/j.jclepro.2018.02.092

Yu S, Gao S, Sun H (2016) A dynamic programming model for environmental investment decision-making in coal mining. Appl Energy 166:273-281. https://doi.org/10.1016/j.apenergy.2015.09.099

Yuab S, Huab X, Fanc J, Chengab J (2018) Convergence of carbon emissions intensity across Chinese industrial sectors. J Clean Prod 194:179-192. https://doi.org/10.1016/j.jclepro.2018.05.121

Zhang Y-J, Hao J-F, Song J (2016) The CO2 emission efficiency, reduction potential and spatial clustering in China's industry: evidence from the regional level. Appl Energy 174:213-223. https://doi.org/10.1016/j. apenergy.2016.04.109

Zheng B, Zhang Q, Tong D, Chen C, Hong C, Li M, Geng G, Lei Y, Huo H, He K (2017) Resolution dependence of uncertainties: a case study in Hebei, China. Atmos Chem Phys 17:921-933. https://doi.org/10.5194/acp17-921-2017 